\title{
Fighting Corruption of the Historical Record: Nazi-Looted Art Litigation
}

\author{
Jennifer Anglim Kreder ${ }^{*}$
}

For the first time in history, restitution may be expected to continue for as long as works of art known to have been plundered during a war continue to be rediscovered.

-Ardelia R. Hall ${ }^{1}$

\section{INTRODUCTION}

Over the years, with a few praiseworthy exceptions, U.S. courts have dismissed many claims to recover Nazi-looted art on technical grounds, causing distortion of the historical record. ${ }^{2}$ This trend seems to reflect bias against these historical claims arising from a lack of historical knowledge. $^{3}$ Tales of venerated institutions, ${ }^{4}$ such as the Museum of Modern Art (MoMA), acquiring what they knew or should have known was trafficked and laundered art may seem outrageous to those unaware of the infection of the market with art that had been stolen or extorted from Jews between 1933 and 1945.

Even when judges recognize the plausibility of such claims, ${ }^{5}$ attending to them requires judicial fortitude and dedication to sorting

* Associate Dean for Faculty Development and Professor of Law, Salmon P. Chase College of Law, Northern Kentucky University; J.D., Georgetown University Law Center. The views expressed in this Article are those of the author only and are not necessarily those of the Kansas Law Review, Inc., its editors, or staff.

1. Ardelia R. Hall, The Recovery of Cultural Objects Dispersed During World War II, 25 DEP'T St. Bull. 337, 339 (1951).

2. See infra Appendix A, Federal Holocaust-Era Art Claims Since 2004 (Oct. 26, 2012) [hereinafter App. A].

3. See infra Part II (detailing how judicial decision-making is prone to bias against Holocaustera claims).

4. Rachel Dubin, Museums and Self-Regulation: Accessing the Impact of Newly Promulgated Guidelines on the Litigation of Cultural Property, 18 U. MiAmI Bus. L. ReV. 101, 101 (2010) ("As ethical guardians of the arts, museums are among the most trusted secular institutions in the United States.”).

5. See Bakalar v. Vavra, 619 F.3d 136, 146-47 (2d Cir. 2010) (recognizing that there may be sufficient evidence to support a claim that a drawing was stolen by the Third Reich). 
through emotionally difficult and complex factual evidence spanning many years. ${ }^{6}$ Regardless of this difficulty and complexity, it is imperative that our courts cease the recent trend of dismissing Holocaustera art cases on impermissible predicates. ${ }^{7}$ In such cases, courts often fail to recognize the need for the assistance of historians to appreciate how seemingly voluntary transactions were in fact the consequences of forced sales - usually with proceeds having been paid into blocked accounts - or sales made under duress to secure flight from the Third Reich. $^{8}$

This Article does not call for judges to ignore technical defenses, such as statutes of limitation, which would require judges to act in contravention of currently applicable law. ${ }^{9}$ Instead, this Article seeks to shed light on which claims and affirmative defenses are actually plausible when the true history of Holocaust-era spoliation and contemporaneous and post-war trafficking is taken into account. Part II details how judicial decision-making, especially under current plausibility pleading standards, is prone to bias against Holocaust-era art claims. Part III lays out essential historical facts that are necessary to determine whether a given claim to Holocaust-era art is plausible. Part IV analyzes the rash of federal court dismissals, and demonstrates how courts could have avoided improper dismissals via judicial notice of obvious historical facts and testimony from historians to understand allegations requiring more thorough explanation. Part V concludes that federal judges should pay keen attention to history to guard against bias creeping into their opinions, which constitute public historical records about the Holocaust.

6. See, e.g., Ralph E. Lerner, The Nazi Art Theft Problem and the Role of the Museum: A Proposed Solution to Disputes over Title, 31 N.Y.U. J. INT'L L. \& POL. 15, 36 (1998) (“[A] matter involving a claim for an artwork stolen during World War II will take between seven and twelve years to resolve."); Press Release, U.S. Attorney, Southern District of New York, United States Announces \$19 Million Settlement in Case of Painting Stolen by Nazi (July 20, 2010), available at http://www.justice.gov/usao/nys/pressreleases/July10/portraitofwallysettlementpr.pdf (providing that, as recently as 2010 , the case that launched the modern era of Nazi-looted art restitution was settled after twelve years).

7. See infra Part IV.

8. See infra Parts III, IV.

9. The author is of the opinion, in light of museums and collectors filing unfair declaratory judgment actions, the law should be changed, but this issue is beyond the scope of this Article. 


\section{Judicial DeCision-Making, Bias, AND PlausibILITy PleAding}

What judges think of their function and task undoubtedly informs their understanding of their power of jurisdiction. Although judges should remain objective, judges are human and their experiences necessarily influence their opinions about whether certain claims are viable. ${ }^{10}$ Additionally, if a judge views the factual allegations of a complaint as implausible at first blush, then the judge may be predisposed to grant a motion to dismiss the case on technical grounds before the expensive, time-consuming discovery phase gains much traction. ${ }^{11}$ As one study posited: "[O]ne would predict that an individual judge will be more likely to dispose of a case on procedural or technical grounds where he lacks particularly strong views or unique expertise in the substantive area of law at issue." 12

One key procedural ground, of course, is a motion to dismiss pursuant to Rule 12(b)(6) of the Federal Rules of Civil Procedure in conjunction with an axiomatic common law rule in the federal system that requires a federal judge ruling upon a motion to dismiss to accept all

10. One article explains this point particularly well:

Our study demonstrates that judges rely on the same cognitive decision-making process as laypersons and other experts, which leaves them vulnerable to cognitive illusions that can produce poor judgments. Even if judges have no bias or prejudice against either litigant, fully understand the relevant law, and know all of the relevant facts, they might still make systematically erroneous decisions under some circumstances simply because of how they-like all human beings - think.

Chris Guthrie, et al., Inside the Judicial Mind, 86 CoRnEll L. REV. 777, 829 (2001); accord LAWRENCE S. WrightSMAN, PSychology AND THE LEGAL SyStem 378 (2d ed. 1991) (relaying shocking admissions by two judges about prejudices influencing their adjudications); Evan R. Seamone, Judicial Mindfulness, 70 U. CIN. L. REV. 1023, 1036-46 (2002) (discussing the influences of judges' past experiences upon their decision-making).

11. See Guthrie, et al., supra note 10, at 783 ("[J]udges make decisions under uncertain, timepressured conditions that encourage reliance on cognitive shortcuts that sometimes cause illusions of judgment."); see also LAWRENCE S. WrightSMAN, Judicial DECISION MAKING: Is PSYCHOLOGY RELEVANT? 12 (1999) ("Each justice is only human, and being human means sometimes making decisions that are self-serving or in other ways biased.").

12. Jonathan R. Macey, Judicial Preferences, Public Choices, and the Rules of Procedure, 23 J. Legal Stud. 627, 632 (1994); see also Richard PoSNER, Overcoming LAW 110 (1995) (positing that most judges are "ordinary judges" although "[s]ome judges have had political agendas"). But see Janet Cooper Alexander, Judges' Self-Interest and Procedural Rules: Comment on Macey, 23 J. LEGAL STUD. 647, 648 (1993) (critiquing Macey's analytical framework and positing that many judges seek to build their reputations); Mark Tushnet, Policy Distortion and Democratic Debilitation: Comparative Illumination of the Countermajoritarian Difficulty, $94 \mathrm{MICH}$. L. REV. 245, 260 (1995) (noting that "we have no good explanations of how the incentives judges face affect the norms they articulate"). 
of a complaint's allegations as true. ${ }^{13}$ However, recent Supreme Court decisions have caused some to question whether the axiom still rings true. ${ }^{14}$ As recently stated by two scholars evaluating Bell Atlantic Corp. v. Twombly ${ }^{15}$ and Ashcroft v. Iqbal ${ }^{16}$ :

[T] he Supreme Court's purpose in developing a more careful judicial review of pleadings was clear: More thorough review is necessary to protect against frivolous and purely speculative lawsuits. Such cases take a considerable toll on the judicial system, wasting scarce judicial resources, delaying justice for meritorious cases, and burdening defendants with "sprawling, costly, and hugely time-consuming" discovery.

In today's post-Twombly-Iqbal climate, the standard by which federal courts determine whether a claim is viable appears to be higher than ever. ${ }^{18}$ The Supreme Court in Twombly and Iqbal "has ushered in the era of so-called 'plausibility pleading,' which... has resulted in significant confusion as lower courts attempt to decipher its meaning and impact."19 According to the Court, "[d]etermining whether a complaint states a plausible claim for relief will . . . be a context-specific task that requires the reviewing court to draw on its judicial experience and

13. See Tellabs, Inc. v. Makor Issues \& Rights, Ltd., 551 U.S. 308, 322 (2007) (holding that when faced with a motion to dismiss, courts must accept all factual allegations in the complaint as true); accord Leatherman v. Tarrant Cnty. Narcotics Intelligence \& Coordination Unit, 507 U.S. 163, 164 (1993) (same).

14. See, e.g., Patricia W. Hatamyar, The Tao of Pleading: Do Twombly and Iqbal Matter Empirically?, 59 AM. U. L. REV. 553 passim (2010) (investigating the impact of recent Supreme Court pleading cases).

15. 550 U.S. 544 (2007).

16. 129 S. Ct. 1937 (2009).

17. Victor E. Schwartz \& Christopher E. Appel, Rational Pleading in the Modern World of Civil Litigation: The Lessons and Public Policy Benefits of Twombly and Iqbal, 33 HARV. J.L. \& PUB. POL'Y 1107, 1109 (2010) (quoting Twombly, 550 U.S. at 557-60, 560 n.6).

18. Id. at 1143-46. See generally Scott Dodson, New Pleading, New Discovery, 109 MiCH. L. REV. 53 (2010) (explaining how the "New Pleading" after Twombly and Iqbal is focused on factual sufficiency, with the purpose of "screening out meritless cases."); Robin J. Effron, The Plaintiff Neutrality Principle: Pleading Complex Litigation in the Era of Twombly and Iqbal, 51 WM. \& MARY L. REV. 1997 (2010) (comparing pleading standards before and after Twombly and Iqbal); Arthur R. Miller, From Conley to Twombly to Iqbal: A Double Play on the Federal Rules of Civil Procedure, 60 DUKE L.J. 1 (2010) (examining implications of the plausibility standard in pleadings); Adam N. Steinman, The Pleading Problem, 62 STAN. L. REV. 1293 (2010) (proposing a "plain pleading" theory as an alternative to both notice and plausibility pleading); Suja A. Thomas, The New Summary Judgment Motion: The Motion to Dismiss Under Iqbal and Twombly, 14 LEWIS \& CLARK L. REV. 15 (2010) (evaluating the similarity of the motion to dismiss and summary judgment standards after Twombly and Iqbal).

19. Schwartz \& Appel, supra note 17, at 1108-09. 
common sense." 20 A number of courts have extended the standard to affirmative defenses as well, ${ }^{21}$ and the time-bar affirmative defenses are key in Holocaust-era restitution cases. ${ }^{22}$ Predictably, the impact of Twombly and Iqbal has been disproportionately felt in those categories of claims where key evidence is uniquely in the hands of the defense-and will not be forthcoming unless and until it is compelled in the discovery phase. ${ }^{23}$ The new standard also skews results in claims that do not seem to comport with "common sense" because they require a deeper level of knowledge to understand them.

Even before Twombly and Iqbal, many would presume at first blush that historical claims, such as claims to Holocaust-era assets, surely must be time-barred. ${ }^{24}$ Such claims are also expensive, complicated, and time consuming, ${ }^{25}$ but not more so than other complex litigation, like tobacco cases. $^{26}$ Although our society has become accustomed to complex

20. Iqbal, 129 S. Ct. at 1950.

21. See Ryan Mize, Note, From Plausibility to Clarity: An Analysis of the Implications of Ashcroft v. Iqbal and Possible Remedies, 58 U. KAN. L. REV. 1245, 1260-61 (2010) (assessing lower court decisions applying plausibility pleadings to affirmative defenses as of 2010).

22. See infra Part IV.

23. See Rakesh N. Kilaru, Comment, The New Rule 12(b)(6): Twombly, Iqbal, and the Paradox of Pleading, 62 STAN. L. REV. 905, 927 (2010) (discussing how in cases where intent is at issue plaintiffs will have inherent difficulty at the pleading stage because "plaintiffs cannot get those documents without discovery, meaning they likely cannot get the documents at all"); A. Benjamin Spencer, Plausibility Pleading, 49 B.C. L. REv. 431, 481 (2008) (observing that under the new pleading standards "although discovery might reveal facts that prove liability, that opportunity is preemptively foreclosed and the investigation for supporting facts that the rules contemplate never occurs. Indeed, it is a greater shame that discovery is foreclosed ... in circumstances where the needed supporting facts lie within the exclusive possession of the defendants ....").

24. See, e.g., Eric A. Posner \& Adrian Vermeule, Essay, Reparations for Slavery and Other Historical Injustices, 103 COLUM. L. REV. 689, 689 (2003) ("Victims of historical injustices who have no positive law claim against wrongdoers often seek reparations from governments, and occasionally they obtain them.").

25. See Monica Dugot, International Law Weekend Panel on Litigating the Holocaust in U.S. Courts, 12 ILSA J. INT'L \& COMP. L. 389, 390 (2006) ("The emotional and financial costs associated with litigation are high. The legal costs can easily end up being a sizable percentage of the actual value of the work. Indeed, the legal costs can easily exceed the value of the work."); Lerner, supra note 6, at 36 ("[A] matter involving a claim for an artwork stolen during World War II will take between seven and twelve years to resolve."); Marilyn Henry, Holocaust Victims' Heirs Reach Compromise on Stolen Art, JERUSALEM Post, Aug. 16, 1998, at 3 (reporting that Thomas Kline, a successful plaintiffs' attorney in the field, has stated: "I am almost at the point where I would say that if the art is worth less than $\$ 3$ million, give up."); see also HOWARD J. TRIENENS, Landscape with Smokestacks: The Case of the Allegedly Plundered Degas 95 (2000) (describing financial realities of bringing a successful claim).

26. See Howard M. Erichson, Coattail Class Actions: Reflections on Microsoft, Tobacco, and the Mixing of Public and Private Lawyering in Mass Litigation, 34 U.C. DAVIS L. ReV. 1, 9 (2000) (discussing the nationwide class action lawsuit Castano v. American Tobacco). 
litigation, ${ }^{27}$ there seems to be a societal bias against claims to recover art stolen or displaced during the Holocaust. ${ }^{28}$ This societal bias has been vetted openly in recent years, as in the following quote:

There should now surely be a statute of limitations on this kind of restitution. If we were still in 1950 and the people who owned the Manet or the Monet were still alive, then it would surely be correct to give these paintings back, but not now and not to grandchildren and great-grandchildren. The world should let go of the past and live in the present. $^{29}$

Often, Jews seeking recovery of art-their own property-are unfairly criticized as being obsessed with money at the expense of the museum-going public. ${ }^{30}$ Public criticism seems to spike after auction of a piece of art restituted from a public museum. ${ }^{31}$ These criticisms reflect uninformed, knee-jerk bias divorced from consideration of history or law.

27. See id. at 2-5 (discussing the "two biggest litigation stories in the United States at the start of the twenty-first century," the Microsoft and tobacco cases).

28. See Alexander Pulte, German Angst Over Return of Kirchner Painting, 9 IFAR J., no. 2, 2007, at 15 (discussing the anger in Germany over the restitution of a Holocaust-era painting that has "generated fear" in those filing restitution claims against German museums for pictures worth millions); Tony Paterson \& David Cox, German Crisis Meeting Called on Nazi Art Sales, TELEGRAPH, Nov. 12, 2006, http://www.telegraph.co.uk/news/worldnews/ 1533955/German-crisismeeting-called-on-Nazi-art-sales.html (describing German museum community's publicly stated fears that its heritage is being "spirited away from public view and sold off for millions to private collectors" at the expense of the public's right to view the work)

29. Sir Norman Rosenthal, Editorial, The Time has Come for a Statute of Limitations, ART NEWSPAPER (Dec. 11, 2008), www.theartnewspaper.com/article.asp?id=16627; see also Ulrike Knöfel, A Question of Morality: An End to Restitution of Nazi Looted Art?, SPIEGEL ONLINE INT'L (Apr. 9, 2009), http://www.spiegel.de/international/germany/0,1518,618400,00.html (discussing Norman Rosenthal's opposition to restitution); SPIEGEL Interview with British Art Expert: 'We Must Live in the Present,' SPIEGEL ONLINE INT'L (Apr. 9, 2009), http://www.spiegel.de/international/germany/0,1518,618399,00.html (interviewing Norman Rosenthal regarding his opposition to the return of art stolen by the Nazis).

30. See Jennifer Anglim Kreder, The Holocaust, Museum Ethics and Legalism, 18 S. CAL. REV. L. \& SOC. JUST. 1, 38 (2008) (documenting such criticisms as harkening to stereotypes of "greedy" Jews and explaining nonfinancial motivations and symbolic value of restitution of Nazilooted art).

31. See Michael Kimmelman, Klimts Go to Market; Museums Hold Their Breath, N.Y. TIMES, Sept. 19, 2006, at E1 (discussing the sale of a Klimt painting and stating that "[a] story about justice and redemption after the Holocaust has devolved into yet another tale of the crazy, intoxicating art market."); Stevenson Swanson, It's 'Our Mona Lisa,' CHI. TRIB., July 14, 2006, at 1 (discussing the world's most expensive painting, a Klimt portrait once seized by the Nazis, going on display in New York). 
These unfair criticisms have been roundly rejected elsewhere, and thus are not the focus of this Article. ${ }^{32}$ Nonetheless, to quickly dispel the notion that such claims cannot be viable under separation of powers doctrines, ${ }^{33}$ it is clear that such claims comport with executive policy, which, since the war, has favored restitution. ${ }^{34}$ Diplomats from the State Department played a leading role ${ }^{35}$ in securing public commitment by the forty-four nations that adopted the Washington Conference Principles on Nazi-Confiscated Art in December 1998. ${ }^{36}$ Principles 1 and 2 of the Washington Principles respectively state that "[a]rt that had been confiscated by the Nazis and not subsequently restituted should be identified" and "relevant records and archives should be open and accessible to researchers, in accordance with the guidelines of the International Council on Archives."37 Additionally, the Terezín Declaration, signed by forty-six countries, including the United States, emerged from the international conference hosted by the Czech Republic in June 2009. ${ }^{38}$ Under the heading "Nazi-confiscated and Looted Art," the Terezín Declaration states:

[W]e urge all stakeholders to ensure that their legal systems or alternative processes ... facilitate just and fair solutions with regard to Nazi-confiscated and looted art, and to make certain that claims to recover such art are resolved expeditiously and based on the facts and merits of the claims and all the relevant documents submitted by all parties. Governments should consider all relevant issues when applying various legal provisions that may impede the restitution of art

32. See Kreder, supra note 30, at 9; Jennifer Anglim Kreder, The New Battleground of Museum Ethics and Holocaust-Era Claims: Technicalities Trumping Justice or Responsible Stewardship for the Public Trust?, 88 OR. L. REV. 37 (2009).

33. See generally, e.g., John F. Manning, Separation of Powers as Ordinary Interpretation, 124 HARV. L. REV. 1939 (2011).

34. E.g., U.S. Holocaust Assets Commission Act of 1998, Pub. L. 105-186, 112 Stat. 611 (codified as amended at 22 U.S.C. § 1621 (2006)) (approved again in 2008 and supporting Holocaust-era restitution).

35. See Stuart E. Eizenstat, Imperfect Justice: Looted Assets, Slave Labor, AND the UNFINISHED BUSINESS OF WORLD WAR II 187-204 (2004).

36. Wash. Conference Principles on Nazi-Confiscated Art, U.S. State Dep’t (Dec. 3, 1998), http://www.lootedartcommission.com/Washington-principles (last visited Sept. 15, 2012). These Principles were reaffirmed in Vilnius, Lithuania, in 2000. Vilnius Forum Declaration, Comm'n for Looted Art in Europe (Oct. 5, 2000), http://www.lootedartcommission.com/ vilnius-forum.

37. Wash. Conference Principles on Nazi-Confiscated Art, supra note 36, Iq 1-2.

38. Terezín Declaration Holocaust Era Assets Conference (June 30, 2009), available at http://www.holocausteraassets.eu/program/conference-proceedings/ declarations/ (follow “TEREZIN_DECLARATION_FINAL.PDF (78,2kB)" hyperlink). 
and cultural property, in order to achieve just and fair solutions, as well as alternative dispute resolution, where appropriate under law.

These recent declarations call for effective, fair, fact-based resolution of Nazi-looted art claims. Judicial attentiveness to what happened seventy to eighty years ago would augment current executive efforts to resolve the unfinished business of World War II and guard against assaults upon truth and memory. ${ }^{40}$

The Washington Principles were sparked in part by guidelines issued by the Association of American Museum Directors (AAMD) in June 1998. ${ }^{41}$ Thus, it is shocking that U.S. museums, often as plaintiffs, assert statute of limitations and laches defenses, in contempt of the Washington Principles, distorting the historical record and law in the process. ${ }^{42}$ Museums that have filed declaratory judgments on technical grounds against claimants include the Boston Museum of Fine Arts, Detroit Institute of Arts, Toledo Museum of Art, and the Guggenheim. ${ }^{43}$ The Norton Simon Museum of Art and MoMA have also raised technical defenses in response to claims. ${ }^{44}$

Moreover, the valuation of the art that deserves to be restituted to its true owners is far from trivial. The injustice of denying restitution is tremendous, not just in symbolic terms.

According to Ronald Lauder [in 1998], a former U.S. ambassador to Austria and now chairman of the Museum of Modern Art in New York, 'more than 100,000 pieces of art, worth at least $\$ 10$ billion in total, are still missing from the Nazi era.' Mr. Lauder believes that 'because of

\section{Id. at $4, \mathbb{9} 3$.}

40. See Deborah E. Lipstadt, Denying the Holocaust: The Growing Assault on TRUTH AND MEMORY 19 (1993) ("These attacks on history and knowledge have the potential to alter dramatically the way established truth is transmitted from generation to generation.").

41. Position Papers \& Reports, Ass'n of Art Museum Dirs., Report of the AAMD Task Force on the Spoliation of Art During the Nazi/World War II Era (1933-1934) (June 4, 1998), http://www.aamd.org/papers/guideln.php [hereinafter AAMD Guidelines] ("AAMD has developed the following guidelines to assist museums in resolving claims, reconciling the interests of individuals who were dispossessed of works of art or their heirs together with the fiduciary and legal obligations and responsibilities of art museums and their trustees to the public for whom they hold works of art in trust."); see also PETER HARClerode \& BRENDAN PITTAWAY, THE Lost MASTERS: WORLD WAR II AND THE LOOTING OF EUROPE'S TREASUREHOUSES 229 (2000) (describing passage of the AAMD guidelines).

42. Kreder, supra note 32 , at 82-83.

43. Id. at $64,66,72$.

44. See App. A, nos. 2, 4 . 
these large numbers, every institution, art museum and private collection has some of these missing works. ${ }^{45}$

These numbers are grounded in historical data interpreted in $1998 .^{46}$ There is now reason to believe the amount of Nazi-looted art trafficked into the United States exceeds previous estimates. ${ }^{47}$

This Article demonstrates how judges should treat Holocaust-era art claims, and how they should reject the recent trend of dismissals. This trend seems to indicate that bias has infected our courts. ${ }^{48}$ In recent years, collectors and museums - treasure houses of high culture and art, and some of the most venerated institutions in the United States-have persuaded federal judges to dismiss complex Holocaust-era art cases without addressing the merits. ${ }^{49}$ This has prevented fact-finding in these cases, contravening executive policy and museums' own ethics guidelines. Moreover, as depicted in the chart entitled Federal Holocaust-Era Art Claims Since 2004 attached to this Article, some judges seem to presume that claims seventy years old cannot be viable. ${ }^{50}$

For example, in Toledo Museum of Art v. Ullin, a district court judge held that the statute of limitations ran in $1943^{51}$ - before the Allies had landed on the beaches of Normandy, let alone defeated the Wehrmacht and liberated survivors in death and work camps. The Ullin court applied Ohio law, finding that if the owner of the painting believed that its sale was wrongful, she could have sought recovery of the painting within the Ohio statute of limitations by $1943 .^{52}$ The court considered the owner's failure to pursue her claim to be evidence that she did not believe the sale of that painting was wrongful. ${ }^{53}$ The court also noted

45. Marilyn E. Phelan, Scope of Due Diligence Investigation in Obtaining Title to Valuable Artwork, 23 SeAtTLE U. L. REV. 631, 660 (2000) (footnotes omitted).

46. Id. at 659 n. 145 .

47. See infra Part III.C.

48. See infra Part IV.

49. See infra notes $158-358$ and accompanying text.

50. See App. A (outlining cases lost by Holocaust victims or their heirs); see also infra Part IV.

51. 477 F. Supp. 2d 802, 809 (N.D. Ohio 2006) (holding contrary to Ohio's use of the demand and refusal principle, which accords with the majority of U.S. jurisdictions). Contra Houser v. Ohio Historical Soc'y, 380 N.E.2d 728, 730 (Ohio Ct. App. 1977) (discussing that special circumstances can delay the presumption that demand was made within the time period of the statute of limitations).

52. Ullin, 477 F. Supp. 2d at 807-08.

53. Id. at 807 . 
that the Ohio statute of limitations, unlike other states', did not contain an exception for Nazi-era art cases. ${ }^{54}$

In fact, so many courts seem to have subjected Nazi-era art cases to a presumption of invalidity that, since the landmark case of Republic of Austria v. Altmann ${ }^{55}$ in 2004, only one claimant has successfully recovered Nazi-looted art in federal court. ${ }^{56}$ In Altmann, Maria Altmann, a then-octogenarian Holocaust survivor, prevailed against the claim of a foreign government that U.S. courts lack jurisdiction over a foreign sovereign that possesses Nazi-looted art. ${ }^{57}$ The Supreme Court held that the Foreign Sovereign Immunity Act of 1976 (FSIA), ${ }^{58}$ the sole means to acquire jurisdiction over a foreign sovereign in the courts of the United States, authorized a Holocaust victim to sue the Republic of Austria for failing to return art to her as the sole survivor of her uncle, who was forced to flee Vienna after the 1938 Anschluss of Austria ${ }^{59}$ - long before the passage of the FSIA. The Supreme Court ruled that because the expropriation was illegal when it occurred, the statutory expropriation exception abridged the blanket immunity that normally would have insulated the Republic of Austria from suit in the United States. ${ }^{60}$ Altmann was able to recover her property only after Austria offered to arbitrate the dispute in Vienna; the republic fought Altmann furiously but lost nonetheless. ${ }^{61}$

Almost incredibly, Altmann was subsequently criticized in such prominent newspapers as the New York Times for getting back her own

54. Id. at 806 .

55. 541 U.S. 677, 733 (2004) (ruling that the Republic of Austria could be sued in the United States under the Foreign Sovereign Immunities Act for conduct that predated passage of the Act). The Act of State Doctrine is beyond the scope of this Article. See generally Lucy Dunn Schwallie, Note, Acts of Theft and Concealment: Arguments Against the Application of the Act of State Doctrine in Cases of Nazi-looted Art, 11 UCLA J. INT'L L. \& ForEIGN AFF. 281, 285 (2006) (discussing the Act of State Doctrine and determining that it is inapplicable where treaties and public policy demand the looted property's return).

56. See Vineberg v. Bissonnette, 548 F.3d 50 (1st Cir. 2008) (the one successful case).

57. Altmann, 541 U.S. at 697-702.

58. 28 U.S.C. $\S \S 1602-1611$ (2006 \& Supp. 2011).

59. A rough translation of Anschluss is "annexation." See AMERICAN HERITAGE DiCTIONARY 55 (William Morris, ed., New College ed. 1976) (defining Anschluss as the political union of Nazi Germany and Austria). See generally Alfred D. Low, The ANSCHLuss Movement, 1931-38, AND THE GREAT POWERS (1985) (explaining in detail the Anschluss Movement).

60. Altmann, 541 U.S. at 706-08 (Breyer, J., concurring).

61. William Grimes, Maria Altmann, Pursuer of Family's Stolen Paintings, Dies at 94, N.Y. TIMES, Feb. 9, 2011, www.nytimes.com/2011/02/09/arts/design/09altmann.html?_r=1 (Altmann "then submitted the case to binding arbitration in Austria" and "[i]n January 2006 the panel awarded [her] ownership of the five paintings."). 
property. ${ }^{62}$ This occurred despite the Republic of Austria forcing her family to make donations of some of the most valuable artwork in the world $^{63}$ to secure any recovery of their significant assets after the war. ${ }^{64}$ People lamented the public's loss of the "Austrian Mona Lisa" ${ }^{65}$ despite the fact that the painting is now on display in the Neue Gallery in New York. ${ }^{66}$

Since Altmann, federal courts have rejected the restitution claims in Nazi-looted art cases on procedural grounds, such as state statutes of limitations and the affirmative defense of laches, except in one case presenting egregious facts. ${ }^{67}$ These cases were wrongly decided without the benefits of expert historians and understanding of the decisional law in this specialized area, ${ }^{68}$ the lack of which hinders victims of the Holocaust and their heirs from reclaiming their property located within the United States. Depriving Jewish claimants of full and fair hearings of these property and inheritance claims in federal courts - the usual venue for diversity suits of this sort — violates the equality inherent in the Due Process Clause of the Fifth Amendment. ${ }^{69}$ In contrast, an unknown

62. See Kimmelman, supra note 31 ("How refreshing this story would have been had the Bloch-Bauers conceived a way to ensure that the birch landscape, say, ended up in public hands.").

63. Carol Vogel, Lauder Pays \$135 Million, a Record, for a Klimt Portrait, N.Y. TimeS, June 19, 2006, www.nytimes.com/2006/06/19/arts/desgin/19klim.html.

64. Altmann, 541 U.S. at 683 (majority opinion); Gerald D. Feldman, Reflections on the Restitution and Compensation of Holocaust Theft: Past, Present, and Future, in ROBBERY AND Restitution: The CONFlict over JeWish Property in Europe 263 (Martin Dean, et al., eds., 2007) ("Austria ... was not only allowed but also encouraged by the Allies to consider itself the 'first victim' of National Socialist German expansion, and could thus, at least until recently, evade responsibility for its own role in Nazi crimes, including the spoliation of the Jews."); see also Richard Z. ChESNOFF, PACK OF ThiEVES: How Hitler AND EuROPE Plundered the JEWS AND COMMITTED THE GREATEST THEFT IN HISTORY 23-43 (1999) (discussing the Austrian government's appropriation of Jewish assets following its annexation of Nazi Germany).

65. Kimmelman, supra note 31. The author does not intend to imply in any fashion that subsequent public display is relevant to whether Holocaust survivors or their heirs seeking their own property deserve criticism for seeking restitution or for what they do with the property after restitution. I believe they do not.

66. E.g., Calev Ben-David, A Priceless Piece of Artistic Justice, Jerusalem Post, June 30, 2006 , at 12 .

67. See Vineberg v. Bissonnette, 548 F.3d 50, 56-59 (1st Cir. 2008) (upholding the district court's rejection of laches defense and order of replevin).

68. E.g., Bakalar v. Vavra, 619 F.3d 136, 143-47 (2d Cir. 2010) (explaining why Kunstsammlungen Zu Weimar v. Elicofon, 536 F. Supp. 829 (E.D.N.Y. 1981), was wrongly decided, namely because the possessor has the burden of proving that a painting is not stolen property).

69. See, e.g., Bolling v. Sharpe, 347 U.S. 497, 499 (1954) ("[D]iscrimination may be so unjustifiable as to be violative of due process.”). Cf. Neithamer v. Brenneman Prop. Servs., Inc., 81 F. Supp. 2d 1, 5 (D.D.C. 1999) ("[D]ismissing a case summary judgment because a plaintiff cannot prove a defendant's suspicions would subject HIV-positive individuals to the very discrimination that Congress sought to prevent, by denying them a remedy even when such discrimination 
number of Nazi-era art cases settle out of court in accordance with the Washington Principles. $^{70}$ The litigated cases reflect either a categorical refusal to permit fact-finding or, worse, a de facto presumption that survivors' and heirs' claims to Nazi-looted art are invalid. The more complex a case, the more attentive courts must be to details; but, a bedrock principle of the judicial system demands that courts afford all litigants an even-handed administration of justice.

\section{NAZI AND WORLD WAR II HISTORY: THE KEY TO ASSESSING THE PLAUSIBILITY OF ART CLAIMS}

In one of the most recently filed appeals of a dismissed Holocaustera art case, the district court characterized the dispute as "a legal, not a historical, question."71 This statement evinces a false dichotomy of the judicial function - judges readily look to history to interpret law, perhaps most notably the Constitution, ${ }^{72}$ because "[t]he linkage between past and present is especially central in law." $" 73$ Judges cannot be expected to know intimately the historical context of all cases that come before them,

existed.").

70. See Thomas R. Kline, Portrait of Notoriety, WALL St. J., July 27, 2010, online.wsj.com/article/SB10001424052748703294904575385543744550822.html ("Quietly ... many [Nazi-looted art] cases are settled with little public notice.”).

71. Grosz v. Museum of Modern Art, 772 F. Supp. 2d 473, 495 (S.D.N.Y. 2010), aff'd, 403 F. App'x 575 (2d Cir. 2010), cert. denied, 132 S. Ct. 102 (2011).

72. See Amy Kapczynski, Historicism, Progress, and the Redemptive Constitution, 26 CARDOZO L. REV. 1041, 1042 (2005) ("[W]e must think historically if we want to think constitutionally...."); see also G. Edward White, The Arrival of History in Constitutional Scholarship, 88 VA. L. REV. 485 (2002) (analyzing the historical turn in constitutional scholarship). Others give lesser import to historical underpinnings in interpreting the Constitution, but virtually no one suggests it is irrelevant. See Ronald Dworkin, The Arduous Virtue of Fidelity: Originalism, Scalia, Tribe, and Nerve, 65 ForDHAM L. REV. 1249, 1249-50 (1997) ("Lawyers and judges faced with a contemporary constitutional issue must try to construct a coherent, principled, and persuasive interpretation of the text of particular clauses, the structure of the Constitution as a whole, and our history under the Constitution ....'); Bruce Ackerman, A Generation of Betrayal?, 65 FoRDHAM L. REV. 1519, 1519 (1997) ("Constitutional meaning ... emerges in the course of the struggle by ordinary Americans to hammer out fundamental political understandings . . . ., fueled by ... crucial historical events...."). Others advocate different methods for interpreting the Constitution, including what could be termed "broad originalism." See Martin S. Flaherty, History "Lite" in Modern American Constitutionalism, 95 ColuM. L. REV. 523, 528 (1995) ("The rediscovery of America's formative constitutional traditions promises a wealth of historical insights closer to home for any theorist inclined to look at the past."). See generally William Michael Treanor, The Original Understanding of the Takings Clause and the Political Process, 95 CoLuM. L. REV. 782 (1995) (analyzing constitutional issues in a historical context).

73. Daniel A. Farber, Adjudication of Things Past: Reflections on History as Evidence, 49 HASTINGS L.J. 1009, 1030 (1998). 
but they should not ignore widely accepted historical facts when deciding the plausibility that a seemingly voluntary transaction was, in fact, made under duress. $^{74}$

Judges even have the power to take judicial notice of widely known historical facts. ${ }^{75}$ As discussed below, as to factual allegations that are less readily understandable, judges should welcome historians into the courthouse to explain whether more-nuanced interpretations of facts are actually plausible. ${ }^{76}$ Because the Nazis used many tactics to mask involuntary transactions in a cloak of legality, documentation of such transactions should be viewed with a cynical, historically informed eye. ${ }^{77}$

From their very first days in power in 1933, the Nazis forced Jews to abandon their property in order to flee. ${ }^{78}$ As a matter of law, fleeing Jews cannot be deemed to have abandoned their property. ${ }^{79}$ The Jews' loss of their property as they fled "for their lives was no more voluntary than the relinquishment of property during a holdup." 80

Moreover, as laid bare below, the historical record leaves no serious doubt that, both during and immediately after the war, art insiders were

74. Cf., e.g., Planned Parenthood of Se. Pa. v. Casey, 505 U.S. 833, 860-65 (1992) (engaging in extensive analysis of history to uphold Roe v. Wade); Michael H. v. Gerald D., 491 U.S. 110, 122-23 (1989) (holding that liberty interests protected by Due Process Clause are fundamental only if "rooted in history and tradition").

75. Toledo Museum of Art v. Ullin, 477 F. Supp. 2d 802, 804 (N.D. Ohio 2006) ("In considering a motion to dismiss the Court may consider "materials in addition to the complaint if such materials are public records or are otherwise appropriate for the taking of judicial notice."” (quoting New England Health Care Emps. Pension Fund v. Ernst \& Young, LLP, 336 F.3d 495, 501 (6th Cir. 2003))).

76. See infra Part IV.

77. See infra Part IV.

78. Raul Hilburg, The Destruction of the European Jews 640-41 (2003) (“When in the early days of 1933 the first civil servant wrote the first definition of 'non-Aryan' into a civil service ordinance, the fate of European Jewry was sealed.").

79. See Restitution of Identifiable Property; Law No. 59, 12 Fed. Reg. 7983, § 3.75 (Nov. 29, 1947) (to be codified at 7 C.F.R. pt. 2100), [hereinafter "Military Government Law 59"] (ordering "speedy restitution of identifiable property ... to persons who were wrongfully deprived of such property within the period from January 30, 1933 to May 8, 1945 ...."); Bakalar v. Vavra, 619 F.3d 136, 149 (2d Cir. 2010) ("Grunbaum never voluntarily intended to pass title to the Drawing. On the contrary, the circumstances strongly suggest that he executed the power of attorney with a gun to his head."); Vineberg v. Bissonnette, 529 F. Supp. 2d 300, 307 (D.R.I. 2007), aff'd, 548 F.3d 50, 53 (1st Cir. 2008) (describing how the victim "surrendered to the inevitable" and fled Germany without ever being able to recover the below market value proceeds from an auction of his painting); Menzel v. List, 267 N.Y.S.2d 804, 810 (N.Y. Sup. Ct. 1996) (holding that no abandonment occurred and that "[t]he relinquishment here by the Menzels in order to flee for their lives was no more voluntary than the relinquishment of property during a holdup ....").

80. Menzel, 267 N.Y.S.2d at 810. 
aware of ${ }^{81}$ the influx of flight-art starting in 1933 and of the Nazi practice of spoliation of Jewish treasures and "degenerate" art. ${ }^{82}$ Hitler, the failed artist, sought to eliminate Jewish culture from the Third Reich, including modern art, which he deemed to be degenerate. ${ }^{83}$ The Nazis maintained "that Jews had intentionally duped the German people into embracing nontraditional aesthetic styles" and "that they had promoted modern art as a ploy to reap huge profits." 84

The Nazi regime's incentive to obtain the fine art of Jewish collectors was, in part, to liquidate it to fund the government. ${ }^{85}$ Additionally, many Nazi leaders were fine art "collectors" and thieves and desired to obtain such pieces for the prestige that was associated with them - even though many paintings and objects had been deemed by the government to be degenerate art. ${ }^{86}$ In the Nazi government's attempt to acquire this art, it used meticulous documentation and falsification of documents to conceal the forced nature of the transactions. ${ }^{87}$ This false documentation can hinder present day claims of art theft because it gives the transactions the superficial appearance of legitimacy. ${ }^{88}$ Additionally, many Jewish families surrendered their valuables under duress to the Nazis to avoid being taken to concentration camps. ${ }^{89}$

On July 5, 1940, the Nazis established the Einsatzstab Reichsleiter Rosenberg (ERR) to track down works of art owned by Jewish people, seize the property, and transfer it to Germany. ${ }^{90}$ To maintain the appearance of legality, the purported goal of this body was to safeguard the works. ${ }^{91}$ The Nazi government also declared some art works to be degenerate and contrary to the German ideology. The Committee for the Assessment of Inferior Works of Art identified and destroyed

81. See infra Part III.B

82. Michael J. Kurtz, America AND the Return of NaZi Contraband 31 (2006); see also Holocaust Victims Redress Act, Pub. L. No. 105-158, § 201(4), 112 Stat. 15, 17 (1998) ("The Nazis' policy of looting art was a critical element and incentive in their campaign of genocide against individuals of Jewish and other religious and cultural heritage ....”); NORMAN PALMER, MUSEUMS AND THE HOLOCAUST 8 (2000).

83. See KURTZ, supra note 82, at 31 .

84. Jonathan Petropoulos, Art as Politics in the Third Reich 54 (1999).

85. See PALMER, supra note 82 , at 3.

86. Id.

87. Id. at $3-4$.

88. See id. at 4. ("This obsession with paper work and legal nicety (particularly the fabrication of voluntary transactions) can hamper the tracing of works . ..." (footnotes omitted)).

89. Id. at 59 .

90. Id. at 7.

91. Id. 
approximately 5,000 of these art works. ${ }^{92}$ Much more degenerate art was seized and sold to generate income for the Nazi government. ${ }^{93}$ The looting of art was widespread and included German museums and art held by private owners outside of Germany. ${ }^{94}$ It is estimated that the Nazis looted over three million art objects from occupied countries. ${ }^{95}$

Immediately after World War II, the Nuremberg Tribunal evaluated detailed evidence of coerced sales of art, and the plunder of art was declared a war crime. ${ }^{96}$ At Nuremberg, it was perfectly clear to the fact finders who had done what and to whom. ${ }^{97}$ Shortly thereafter, in Bonn and Vienna, it was equally clear that to rejoin the human family, Germany and Austria had to repudiate all spurious "transactions" of the entire Nazi era, including art deals that were actually seizures. ${ }^{98}$ It is distressing that in a federal courtroom today what used to be as clear as day has now become as obscure as the "night and fog." 99

We must ensure that our federal courts do not endorse distortions of the historical record by granting motions to dismiss claims on statute of limitations and laches grounds, which impliedly accept that today's claimants are at fault for not demanding their property back from some of the nations' most powerful institutions. This is necessary even though the key to the claims - information-was inaccessible during the Cold War and, too commonly, remains locked away to this day, often by individuals and institutions right here in the United States. ${ }^{100}$

92. Id. at $7-8$.

93. Id. at 8 .

94. Id. at 9 .

95. Id. at 11 (quoting CHESNOFF, supra note 64, at 38).

96. Wilfried Fiedler, Legal Issues Bearing on the Restitution of German Cultural Property in Russia, in THE SPOILS OF WAR 178 (Elizabeth Simpson ed., 1997) ("The Nazi War criminals were accused of 'pillage and destruction' of works of art, including both private and public property .... The judgment of the Nuremberg trials stated: '. . that it was supported by evidence that the territories occupied by Germany had been exploited in the most merciless way and that actually a systematic plundering of public and private property had taken place."')

97. For example, Alfred Rosenberg, head of the infamous ERR art looting unit, was convicted and sentenced to death by hanging. Charter of the Int'l Military Tribunal, Alfred Rosenberg, (Aug. 8, 1945), http://www.law.umkc.edu/faculty/projects/ftrials/nuremberg/NurembergIndictments.html\# Rosenberg (last visited Oct. 16, 2012).

98. E.g., Military Government Law 59, supra note 79 (ordering return of identifiable property to persons who were deprived of it between January 30, 1933 and May 8, 1945).

99. See Benjamin E. Pollock, Out of the Night and Fog: Permitting Litigation to Prompt an International Resolution to Nazi-looted Art Claims, 43 Hous. L. REV. 193, 195 (2006) (arguing that claims concerning Nazi-looted art should be heard in U.S. courts).

100. See Grosz v. Museum of Modern Art, 772 F. Supp. 2d 473, 481-89 (S.D.N.Y.) (discussing MoMA's refusal to provide access to provenance documents despite public statements to the contrary), aff'd, 403 F. App'x 575 (2d Cir. 2010), cert. denied, 132 S. Ct. 102 (2011); see also infra 
In 1998, MoMA director Glenn Lowry acknowledged in congressional testimony the "rapacity of the Nazis and their collaborators," estimating that the Nazis stole "[t]ens of thousands" of pieces of art. ${ }^{101}$ Lowry and other high-profile museum directors swore in Congress that they would conduct research and devise a system to remedy this great injustice. ${ }^{102}$

Another historian has stated: "The paintings came to America because for more than 10 years during and after the war there was no place else to sell them...." "103 Yet, since the 1998 promises in Washington and Terezín to open up archives, make them searchable, help claimants discover their property, and resolve claims fairly and equitably, fewer than forty paintings have been restituted by U.S. museums. ${ }^{104}$ More cash settlements have been made, usually quietly. ${ }^{105}$ Some museums have put forth a good faith effort to conduct and publicize provenance research needed to identify art displaced during the Holocaust; ${ }^{106}$ other museums hide behind the expense of performing

Part IV.B.

101. Press Release, Comm. on Fin. Servs., Testimony Before the House Banking \& Fin. Servs. Comm. by Glenn D. Lowry, Director, The Museum of Modern Art, N.Y. (Feb. 12, 1998), http://archives.financialservices.house.gov/banking/21298low.shtml.

102. Walter V. Robinson, Museums' Stance on Nazi Loot Belies Their Role in a Key Case, Boston GlOBE, Feb. 13, 1998, at A1.

103. Adam Zagorin, Saving the Spoils of War, TIME, Dec. 1, 1997, at 87 (quoting Willi Korte, consultant on Holocaust losses to the Senate Banking Committee); see also Lucille A. Roussin, Holocaust-Era Looted Art: The Routes Into the U.S., 5 IFAR J., no.3, 2002, at 36.

The market remained rationed until at least 1951. In the previous years heavy price rises could only be sustained by purely native or resident buyers in such protected areas as the U.S.A. In the early fifties it was still said that the cheapest thing you could buy was a work of art.... Nor were the prices of the later fifties, particularly the prices of nineteenth and twentieth-century French art, altogether the 'coup de foudre' which the popular Press made them to be.

Id. (quoting Gerald Reitlinger, The ECONOMics OF TASTE 220 (1961)). Professor Roussin has documented the importation process and how looted paintings entered the United States without investigation, including a shipment by the Galerie Fischer in Lucerne, Switzerland, which was known to have dealt with the Nazis. See id. at 39.

104. See Mark Stryker, The Art of the Matter: The DIA and Toledo Museum of Art Could Lose a Van Gogh and a Gauguin Worth Millions in a Dispute with the Heirs of a Woman Who Sold the Works in the Nazi Era. But was she Pressured to Settle for Less?, DETROIT FreE PrESS, Mar. 19, 2006, at L1 ("There have been about 30 claims made on U.S. museums for Nazi-looted art in the last decade, a dozen of which resulted in the pieces being returned or in restitution, according to the American Association of Museums. Most cases are resolved through quiet compromise. Arbitration panels are becoming standard in Europe but haven't caught on in the United States.").

105. See Kline, supra note 70 ("Quietly, however, many cases are settled with little public notice.").

106. E.g., Celestine Bohlen, National Gallery to Return a Family's Painting Looted by the Nazis, N.Y. TIMES, Nov. 21, 2000, at E1 (reporting that Frans Snyders' stolen painting "Still Life 
provenance research as an excuse not to do it. ${ }^{107}$ This excuse undoubtedly will gain more traction in the current economic climate.

Despite such excuses, some museums have managed to reach deep into their pockets to initiate costly litigation to shut down claims before allowing claimants to research their archives. This action blatantly contradicts promises museums made to Congress. And in the case of the MoMA, in blatant contradiction to its own website, which states that its archives "serve[] outside researchers as well as Museum staff."108

The conclusion that there is almost no looted art in our institutions simply is not plausible. Without discovery of the documents necessary to fill in the gaps in the historical record, claims cannot succeed and our courts help distort truth and memory. The following is a brief rendition of the key historical facts we do know, which should inform judicial decision-making in the field.

\section{A. Inside the Reich}

Judges faced with Nazi-era art claims should fully consider the historical reality of the Nazi era in Europe. The National Socialist platform, adopted as official German state policy in 1933, was committed to driving Jews and other "enemies of the State" out of economic life. ${ }^{109}$ The Führerprinzip ${ }^{110}$ demanded unquestioning loyalty to the concentrated power of a unitary executive. ${ }^{111}$ Both legislators and judges in Nazi Germany helped to normalize practices of state grand theft that were engineered to make involuntary transactions appear

with Fruit and Game" was donated to the National Gallery of Art in 1990, but through curator Nancy Yeide's extensive research effort, the gallery decided to return the painting in November of 2000).

107. See Earl A. Powell, III, Director, Nat'l Gallery of Art, Address to the Plenary Session on Nazi-Confiscated Art Issues at the Wash. Conference on Holocaust-Era Assets, 470 (Dec. 1, 1998), fcit.usf.edu/holocaust/resource/assets/heac4.pdf (explaining that provenance research is a "time consuming, expensive kind of research.").

108. About the Archives, MoMA, http://www.moma.org/learn/resources/archives/archives about (last visited Aug. 28, 2012).

109. See, e.g., Martin DeAn, RobBing the JeWs: The Confiscation OF JeWish Property in THE HolOCAUST, 1933-1945, at 25 (2008); INGO MÜller, Hitler's JustiCE: THE COURTS OF THE THIRD REICH 115-19 (1991).

110. David Welch, The Third Reich: Politics and Propaganda 107 (2d ed. 2002) (describing Führerprinzip as a mystical notion of a leader guiding the nation's destiny, resulting in commands coming from a centralized leader rather than choices made by the people).

111. Frederick L. Schuman, The NaZi Dictatorship: A Study in Social Pathology and THE POLITICS OF FASCISM 120-24 (1972). 
"ordinary and legal" from the very first weeks of the Nazi regime; ${ }^{112}$ this was before the infamous racist Nuremberg laws of "blood and honor" in 1935 and the push to a "Final Solution." As later observed by the U.S. Consul General in Vienna immediately after the Anschluss of Austria in March 1938: "There is a curious respect for legal formalities. The signature of the person despoiled is always obtained, even if the person in question has to be sent to Dachau in order to break down his resistance." $" 113$ Thus, theft of Jewish-owned art usually was disguised by the appearance of legality.

Quite problematic in the context of distinguishing voluntary from involuntary transactions was the application of the Flight Tax. The Flight Tax preexisted the Nazis' rise to power but was turned to evil ends to persecute Jews even as they were trying to flee, and the extortion was especially compounded by the blocking of Jews' bank accounts starting in 1940. ${ }^{114}$ The Flight Tax confiscated much of a fleeing Jewish family's wealth, which gave rise to the dilemma of whether a Jewish family should give up all its property for a chance of escape or remain in Germany with the hope that the restrictions would dissipate with time. ${ }^{115}$ Beginning in 1940, the Nazis also blocked all payments into Jewish bank

112. Bakalar v. Vavra, 619 F.3d 136, 138 n.2 (2d Cir. 2010) ("Lawyers were everywhere and their influence was pervasive. Again and again, there was a need for legal justifications." (quoting Raul Hilberg, Perpetrators Victims Bystanders: The Jewish Catastrophe, 1933-1945, at $71(1992)))$. The Bakalar court also cited the following sources with approval: CHESNOFF, supra note 64, at 33-35 ("To give some legal fiction to its theft of Jewish property, the Nazis had promulgated a 'Law for the Compensation of Damages Caused to the German Reich by Jews.'"); Henry Friedlander, Nazi Crimes and the German Law, in NAZI CRIMES AND THE LAW 16-17 (Nathan Stolzfus \& Henry Friedlander, eds., 2008) (explaining widespread nature of the respect for legal formalities within the Reich); Richard LaWrenCE Miller, NAZI Justiz: LAW OF THE HOLOCAUST 1 (1995) (“[O]bedience to legal forms strengthened [the Reich's] power. Upstanding citizens felt a moral obligation to submit to the law's authority .... Resistance was immoral. If any citizens felt unease about a particular policy, their pained consciences were salved via display of a suitably stamped document in pursuance to a decree."); Peter Hayes, Summary and Conclusions, in Confiscation of Jewish Property in Europe, 1933-1945: New Sources and Perspectives 143, 147 (2003) (The law "removed the question of the morality or legitimacy of the process.").

113. William L. SHiRER, THE NightMARE YeARS, 1930-1940, at 30 (1992).

114. ESTHER TISA FranCinI, ET AL., INDEP. EXPERT COMM'N SWITZ.-WWII FLIGHT GOODSStolen GoOds: The Transfer of Cultural ASSETS IN AND Via SwitZerland 1933-1945 AND THE QUESTION OF RESTITUTION 319 (2001) (providing example of woman committing suicide because she could not emigrate due to the "Reich Escape Tax.") (translation on file with the Kansas Law Review). See generally HeCtor Feliciano, The Lost Museum: The NAZI ConsPiracy to STEAL THE WORLD's GREATEST WORKS OF ART 155-64 (1997) (detailing how Nazi authorities traded or sold numerous works of art to Swiss traders in the early 1940s).

115. Gerald D. Feldman, Confiscation of Jewish Assets, and the Holocaust 4 (2003) ("The Reich 'Flight Tax,' for example, was created by the Brüning regime in 1931 to prevent capital flight from Germany; it did so by forcing emigrants to pay twenty-five percent of their assets."). 
accounts and placed harsh restrictions on how much money Jews could withdraw from their own accounts. ${ }^{116}$

From the very beginning of the Nazi era, law and jurisprudence were strong components of the justification of regulations that deprived enemies of the state ${ }^{117}$ of their liberty and property; deprivations led to mass murder. ${ }^{118}$ Indeed, the legalized grand larceny helped to finance the mass murder. ${ }^{119}$ It is crucial for judges today to understand that Jews were systematically excluded from professions and forced to compile inventories to streamline the despoliation of their property from 1933 to 1942, when Jews had little or no property left to rob, and when the Nazis' focus turned to cost-efficient mass murder in the death camps of occupied Poland. ${ }^{120}$

It distorts historical reality to suggest that the financial despair of Jews in 1933, during widespread, sporadic boycotts, until the passage of the first Nuremberg law in 1935 was the result of a series of isolated private setbacks brought about by generalized severe financial conditions akin to the Great Depression. ${ }^{121}$

After the seizure of power in early 1933, the effects of a series of boycotts, discriminatory treatment, and specific legal measures rapidly undermined the position of Jewish business, employees, and professionals. Jews were not only excluded from government service,

116. Id.

117. CHESNOFF, supra note 64, at 8 ("For Adolf Hitler and his most willing executioners, Jews were a cancer on society, a malignancy that had to be surgically but brutally excised with no anesthesia: The Jews of the world, declared Hitler, are "vermin."').

118. See, e.g., MÜLLER, supra note 109, at 21 ("[T] recognize the violent character of the National Socialist Movement.").

119. See DEAN, supra note 109, at 2 (explaining the Nazis' "application of pseudo-legal and bureaucratic methods is also the defining characteristic of the confiscation of Jewish property."); see also Götz Aly, HitLer's BenEficiaries: Plunder, RACIAL WAR, AND the NAZI Welfare STATE 6 (2007) (explaining that public enthusiasm for anti-Semitic policy "can generally be observed whenever a part of society claims the right to rationalize other people's property."); DAVID Cesarani, Becoming Eichmann: Rethinking the Life, Crimes, and Trial of a "Desk MURDERER" 67 (2004) (detailing Eichmann's bureaucratic policies to seize money and property from emigrating Jews); RICHARD J. EVANS, THE THIRD REICH IN POWER 1933-1939, at 392 (2005) ("Aryanization did indeed offer many opportunities to non-Jewish businesses and businessmen to enrich themselves.").

120. See DEAN, supra note 109, at 379 ("[L]aws excluding [Jews] from the civil service and other professions ... steadily drove the Jews out of the German economy.").

121. See AVRaham Barkai, From Boycott to Annihilation: The EConomic Struggle of GERMAN JEWS 1933-1943, at 5-6 (1989) (explaining "Jews had been harder hit by the postwar economic crisis" and "[t]he anti-Semitic boycott had already begun... and was intensified particularly during the 1929-1932 Depression"); EvANS, supra note 119, at 544 (detailing how the Nuremberg laws reduced Jews to "subjects of the state"); see also infra notes 267-313. 
but state and Nazi Party initiatives progressively drove them out of many other trades and professions. Large numbers of Jews emigrated or ran into economic difficulties, so that more than half of all Jewish businesses were sold or liquidated by the summer of 1938 .

In 1935, James McDonald resigned on moral grounds from his post as High Commissioner for Refugees. ${ }^{123}$ McDonald detailed the economic devastation of German Jews and noted that many wanted to flee but could not because of financial predation occurring between 1933 and 1935. ${ }^{124}$ High Commissioner McDonald's resignation was reprinted in the New York Times, ${ }^{125}$ which begs the next issue: Did purchasers and recipients of donations of art know where it came from-and what could survivors or their heirs do about it?

\section{B. Knowledge of Spoliation Outside the Reich Highly Relevant to Good Faith Purchaser Status Under Foreign Law, Statutes of Limitation, Laches Defenses, and Equitable Tolling}

Some American museums uphold that the art world was oblivious to the infection of the market until 1998, but the story of the Nazis stealing more art than any regime in history, surpassing even Napoleon, was widely told-even front page news. ${ }^{126}$ Theodore Rousseau, a former officer of the Office of Strategic Services (OSS) who became a curator of paintings at the Metropolitan Museum of Art, thought it was "absurd" for American museums to miss out on the fire sales: "[I]t's absurd to let the Germans have the paintings the Nazi bigwigs got, often through forced sales, from all over Europe. Some of them ought to come here [to American museums]."

\footnotetext{
122. EVANS, supra note 119, at 18.

123. Text of Resignation of League Commissioner for German Refugees, N.Y. TIMES, Dec. 30, 1935.

124. Id.

125. Id.

126. See, e.g., Milton Esterow, Europe Is Still Hunting Its Plundered Art: Hundreds of Millions in Treasures Elude Postwar Search, N.Y. TIMES, Nov. 16, 1964, at 1 (reporting many countries were seeking art looted mostly by Nazis during World War II); Francis Henry Taylor, Europe's Looted Art: Can it be Recovered?, N.Y. TIMES, Sept. 19, 1943, at SM18 ("Not since the time of Napolean Bonaparte has there been the wholesale looting and destruction of art property that is going on today in the occupied countries"); Otto D. Tolischus, Hitler will Seize Property of Foes, N.Y. TIMES, July 15, 1933, at 1 (announcing Hitler adopted decrees providing for confiscation of all property belonging to those hostile to the regime).

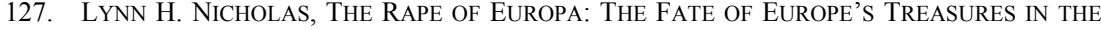
THIRD REICH AND THE SECOND WORLD WAR 438-39 (1994).
} 
to the Nazis' liquidation of degenerate art from Germany's own museums. ${ }^{128}$

As early as 1933, the New York Times published articles documenting Nazi seizures of property written by critics of the Nazi regime. ${ }^{129}$ The Times decried: "To Be a Jew Is Held a Crime." 130 As of January 1, 1936, Professor Karl Loewenstein wrote for the Yale Law Journal:

Jews are finally driven out even from the remaining nooks and crannies of economic life by the official economic boycott, more or less endorsed by the courts. Obligations of contract, vested rights, the right to dispose freely of property, were superseded by political coordination. Legal titles were voided and property confiscated under the pressure of party members and officials.

Judges in New York understood these facts as early as $1936 .{ }^{132}$

In a 1938 letter to a Guggenheim Foundation curator, the famous artist Otto Nebel described the Nazis' plans to liquidate degenerate art: "[T]he entire German museum collections in modern art are involved! ... I believe that one shouldn't help transform works of art into armaments - and that, after all, would be the end result. But that is my own opinion, and it needn't bother anyone." ${ }^{133}$ Francis Henry Taylor, former Director of MoMA, also condemned Nazi-looted art trafficking in the New York Times in 1943. ${ }^{134}$

In 1943, the United States joined all Allied powers in issuing the Declaration Regarding Forced Transfers of Property in EnemyControlled Territory, also known as the "London Declaration," warning art buyers that the Nazis were using false paperwork to fabricate provenances. ${ }^{135}$ Two years later, the Roberts Commission, chaired by

128. See id. at 438 (quoting a telegram from the Acting Secretary of State Lovett who addressed Theodore Rousseau as the American museum official who was "openly advocating the sale of objects from Nazi and German public collections.").

129. Tolischus, supra note 126, at 1 .

130. German Fugitives Tell of Atrocities at Hands of Nazis, N.Y. Times, Mar. 20, 1933, at 5.

131. Karl Loewenstein, Law in the Third Reich, 45 YALE L.J. 779, 797, 807 (1936).

132. See Holzer v. Deutsche Reichsbahn Gesellschaft, 290 N.Y.S. 181 (N.Y. Sup. Ct. 1936), aff'd, 299 N.Y.S. 748 (N.Y. App. Div. 1937), aff'd in part, modified in part, 14 N.E.2d 798 (N.Y. 1938).

133. JoAn M. LuKACh, Hilla Rebay: In SEARCh of the SpIRIT IN ART 121 (George Braziller, ed., 1983).

134. See Taylor, supra note 126, at SM18 (supporting the formulation of an American Commission to deal with Nazi-looted art).

135. 8 DEP'T ST. BULl. 21(1943). 
Supreme Court Justice Owen Roberts, issued written warnings to American museums against acquiring stolen artworks and asked for cooperation in researching and returning such artworks. ${ }^{136}$ The American Commission for the Protection and Salvage of Artistic and Historic Monuments in War Areas publicized a circular in 1945 stating:

It is, of course, obvious that no clear title can be passed on objects that have been looted from public or private collections abroad. We believe, therefore, that it is to the advantage of both public institutions and the trade, as well as for the good name of this Government and its armed forces, that any specific examples of looting of works of art or cultural materials be brought to light as soon as possible. ${ }^{137}$

Later on December 11, 1950, the State Department's Division of Libraries and Institutes also wrote to all museums and art dealers and asked for help in spotting and returning artworks stolen from European public and private collections. ${ }^{138}$

Moreover, the "Monuments Men" of the Monuments, Fine Arts and Archives Program (MFA\&A) sought tirelessly to secure tremendous caches of stolen art to restore it to the source countries of victims. ${ }^{139}$ After the Monuments Men's return from Germany, many from the program became museum directors and academics in prestigious colleges and universities, where they told their stories. ${ }^{140}$ After the war, the State Department and other agencies, governments, and organizations issued

136. Letter from The Am. Comm'n for the Prot. \& Salvage of Artistic \& Historic Monuments in War Areas to Museums, Art \& Antique Dealers \& Auction Houses (1945) (on file with author).

137. Id.

138. Letter from Dep't of State to Univs., Museums, Libraries, Art Dealers, \& Booksellers (Dec. $11,1950)$ (on file with author).

139. See Charles de JAEger, The LinZ File: Hitler's Plunder of Europe's ART 104 (1981) (discussing how the MFA\&A assessed damage to art and monuments in Europe); HENRY LA FARGE, LOST TREASURES OF EUROPE 11 (1946) ("The information on war damage in Italy is very complete, due to the excellent work of the Monuments and Fine Arts officers ...."); JAMES J. Rorimer, Survival: The SAlvage AND Protection of ART IN WAR 233 (1950) ("[A]ny attempt to give the complete story of the works of the enthusiastic, able and hard-working specialist officers at the Collecting Points and to tell the complete story of MFA\&A work in Germany, would require another book."). James Rorimer, who later became Director of the Metropolitan Museum, on March 14, 1944, met in person Rose Valland who scrupulously documented Nazi looting through the Jeu de Paume in Paris at great risk to her life. ROBERT M. EdSEL \& BRET WitTER, The MONUMENTS MEN: Allied Heroes, NAZI Thieves, AND the Greatest Treasure Hunt In History 134-35 (2009). Some art collectors told stories of having purchased looted art. WILliam S. PALEY, AS IT HAPPENED, A MEMOIR 102 (1979).

140. See, e.g., THE MONUMENTs MEN, www.monumentsmen.com/monumentsmen.php (last visited Oct. 16, 2012) (providing examples of Monuments Men who became museum directors, museum curators, and educators, among other professions). 
warnings about looted objects infecting the market and publicized lists of stolen art and the identities of traffickers, including two names found in the provenance records in Grosz v. Museum of Modern Art, ${ }^{141}$ discussed below. ${ }^{142}$ Additionally, on October 4, 1954, a State Department report written by renowned art historian Ardelia R. Hall thanks numerous American museums for assisting in restituting manuscripts and art that had been taken from German municipal collections. ${ }^{143}$

News stories ran in publications such as The New Yorker, which published a series of three articles in 1947 by the renowned cultural commentator Janet Flanner detailing the massive character of the Nazis' spoliation of Jewish and other degenerate art. ${ }^{144}$ For example, on March 1, 1947, Flanner described how Walter Hofer, a Berlin art dealer, who "with Göring behind him . . . could travel wherever he wished (usually in a Luftwaffe plane), compare markets, meet the bigwigs, and, above all, promise Nazi protection to those who were willing to exchange art for safety, dirt cheap." "She continued: "It was Hofer who worked out the heartless, shifty, pseudo-legitimate, semi-blackmail technique that characterized Göring's wartime art deals, as distinguished from Göring's art thefts." $" 146$

141. 772 F. Supp. 2d 473 (S.D.N.Y.), aff'd, 403 F. App'x 575 (2d Cir. 2010), cert. denied, 132 S. Ct. $102(2011)$

142. See infra Part IV (explaining the dismissal of Holocaust-era art claims).

143. Ardelia R. Hall, U.S. Program for Return of Historic Objects to Countries of Origin, 19441954, 31 DEP'T ST. BULL. 493, 496 (Oct. 4, 1954). Hall thanked the following museums:

[T] he Smithsonian Institution, the Library of Congress, the Freer Gallery of Art, the National Gallery of Art, the Los Angeles County Museum, the University of Florida, the Art Institute of Chicago, the John Herron Art Institute of Indianapolis, the Museum of Fine Arts of Boston, the Fogg Museum of Art and the Busch-Reisinger Museum of Harvard University, the Detroit Institute of Arts, the Palace of the Legion of Honor Museum of San Francisco, the Duluth (Minnesota) Public Library, the Columbus (Ohio) Public Library, the Princeton University Library, the New York Public Library, the Frick Art Reference Library, the Morgan Library, the Cornell University Library, the Syracuse University Library, the Numismatic Society of New York, the Institute of Fine Arts of New York University, the Frick Collection, the New York Historical Society, the University of Pennsylvania Library, the Philadelphia Museum of Art, the Rhode Island School of Design, the Museum of Williams College, the Museum of Houston (Texas), and Lawrence College.

Id.; see also id. at 495 ("The recovery of these manuscripts and of other rare books and objects of art dispersed during or following World War II has been a part of U.S. Government policy.").

144. Janet Flanner, Annals of Crime: The Beautiful Spoils, NEW YorkeR, Feb. 22, 1947, at 31; id. Mar. 1, 1947, at 33; id. Mar. 8, 1947, at 38.

145. Id. Mar. 1, 1947, at 34 .

146. Id. Flanner also details how the Dutch art market, which "had been frozen by the fear of the war, but under Nazi heat it thawed out and had its biggest boom in modern times," was infected by the expropriation of the large Jacques Goudstikker gallery, after he attempted to flee, which 
Interest revived in Holocaust-era assets in the 1990s, after declassification of a number of archives, ${ }^{147}$ which allowed some to begin the costly search for family assets and assert various legal claims; the revival, however, did nothing to negate the fact that the art world had contemporaneous knowledge about the massive infection of the market starting in 1933 and festering through today. Museums knowingly acquired or accepted donations of paintings that were - or very likely were-stolen directly from Jews or sold by Jews under duress. ${ }^{148}$ Not caring does not equate to not knowing. The law dictates that such transfers were and still are void. ${ }^{149}$ As succinctly stated by one student of the field whose work was cited on this point with approval by the United States Court of Appeals for the Second Circuit: "[A]bsent other considerations an artwork stolen during World War II still belongs to the original owner, even if there have been several subsequent buyers and even if each of those buyers was completely unaware that she was buying stolen goods." ${ }^{150}$ Thus, absent a technical defense, claims to such art should succeed today. ${ }^{151}$

contained art from Goudstikker's own collection, as well as art owned in shares by many Jews who could not safely come to claim it after the Nazi takeover. Id. at 35. "Göring enjoyed first pick of the Goudstikker stock." Id. She also described the role of Paris dealer Alois Miedl, who had traded with Göring to get his wife to safety in Switzerland, in trafficking through Switzerland, "where French moderns were prized and were accepted at face value." Id. at 38. Moreover, after the war, the Dutch government, before eventually restituting the Goudstikker collection in 2008, characterized the family's approach to restitution in laches-type language to justify retention of the collection:

As you can see, wrote Dutch Foreign Minister Hans van Mierlo, after the war, Jacques Goudstikker's widow, Mrs. Goudstikker-Von Halban, chose consciously, and on the basis of expert legal and other advice, not to reclaim title to the paintings sold to Goering by her late husband's art dealership. Instead, she chose to keep the money she had received for them, but at the same time, elected to reclaim title to real estate and other property sold to Mr. Miedl....

GREGG J. RICKMAN, CONQUEST AND REDEMPTION 239 (2007).

147. E.g., Michael J. Bazyler, Holocaust Justice: The Battle for Restitution in AMERICA'S COURTS, at xi (2003) ("It is only now, with the intervention of the American courts, that elderly Holocaust survivors throughout the world are starting to see hope for compensation at last being realized.").

148. E.g., MoMA acquired one of the Grosz paintings at issue in 1946, and another in 1954. Grosz v. Museum of Modern Art, 772 F. Supp. 2d 473, 476 (S.D.N.Y.), aff'd, 403 F. App'x 575 (2d Cir. 2010), cert denied, 132 S. Ct. 102 (2011). The Toledo Museum of Art acquired a tainted Kokoschka in 1947. Kreder, supra note 32, at 72.

149. See Military Government Law 59, supra note 79; see also Bakalar v. Vavra, 619 F.3d 136, 140 (2d Cir. 2010) (noting that "[u]nlike Switzerland, in New York, a thief cannot pass good title.").

150. Michelle I. Turner, Note, The Innocent Buyer of Art Looted During World War II, 32 VAND. J. TRANSNAT'L L. 1511, 1534 (1999), cited with approval in Bakalar, 619 F.3d at 141.

151. For a discussion of the legal principles dictating restitution in such cases under U.S. law not 
In conclusion, some current possessors of this property, including some of the world's most esteemed museums like the MoMA, have essentially argued that Jews and opponents of National Socialism were able to freely and voluntarily transfer their property within the Third Reich after 1933. This may have been possible in some instances, ${ }^{152}$ but was emphatically not true in general. ${ }^{153}$ Additionally, as it was almost futile to try to reclaim such transferred and looted art until recently, ${ }^{154}$ how should statute of limitations and laches defenses apply? Furthermore, as Part III.C., discusses, it seems that we have only begun to scratch the surface of the historical record to understand the flimsiness of most assertions by art-world insiders of bona fide purchaser status. ${ }^{155}$ In other words, cases to date have implicated only the most superficial level of evidence as to what buyers and donees knew when they came to possess Nazi-looted art, and courts should not continue to give presentday possessors the benefit of the doubt in contravention of the standard

including other sources cited throughout this Article, see Bert Demarsin, Has the Time (of Laches) Come? Recent Nazi-Era Art Litigation in the New York Forum, 59 BufF. L. REV. 621 (2011) (surveying Nazi-era artwork litigation in New York).

152. See PALMER, supra note 82 at 59-60; see also Petropoulos, supra note 84, at 60-61 (discussing the public sales of art in the 1930s); Judy Dempsey, Germany Tracing Artwork and Its Nazi Past, N.Y. TimeS, Dec. 22, 2008, http://www.nytimes.com/2008/12/22/world/europe/22ihtletter.4.18871861.html? $\mathrm{r}=2$ ("“There is the issue of enforced transactions of every sale of every Jewish collection that happened during the Nazi times,' said [Sean] Rainbird, a former curator of the Tate Modern in London. 'There were cases where individuals were allowed to take their collections out of the country, and there were some dealers, in a gesture of solidarity, who helped them and were dealing with them in an honest way."'); see also Zagorin, supra note 103, at 87 (inferring opposition to compensating claimants for works sold in the 1930s at what seemed to have been fair prices in that market and noting that the art market in New York "continued to function even as fighting raged in Europe.").

153. E.g., Sydney M. Drum, Comment, DeWeerth v. Baldinger: Making New York a Haven for Stolen Art?, 64 N.Y.U. L. REV. 909, 944 (1989) ("Because stolen art work can be very valuable, may eventually filter into the open market, and may be handled by the shadowy institution of the art gallery, art owners may be victimized by international trading in stolen art. Original owners, however, have only a few fragmentary and little-known mechanisms by which to register or recover their stolen art objects."), cited with approval in Bakalar, 619 F.3d at 141.

154. Michael J. Reppas II, Empty "International” Museums' Trophy Cases of Their Looted Treasures and Return Stolen Property to the Countries of Origin and the Rightful Heirs of Those Wrongfully Dispossessed, 36 DENV. J. INT'L L. \& POL'Y 93, 94 (2007) (“The dawn of the 21st Century has brought a fresh breeze to the stale and stagnant course of requests for looted property to be voluntarily returned and the invariable refusal by the international museums. The long held assumptions of nation-states and individuals that they are unable to challenge the museum's ownership of these treasures, has changed to a more confident and confrontational stance whereupon they now believe they can legally compel the museums to return their looted treasures.").

155. See Bakalar, 619 F.3d at 148 (Korman, J., concurring) (describing how the purported Swiss transaction was premised on obvious lack of title in supposed seller yet the trial judge enforced such title). 
application of Rule 12(b)(6). ${ }^{156}$ If almost an entire industry blocks recovery, how should these doctrines apply?

\section{Going Forward in Our Courts and Pursuing Truth and Memory}

The historical context outlined above should inform judges' views of the plausibility of claims and defenses in Holocaust art cases. By reducing the level of skepticism infecting first impressions of these historic claims, this Article seeks to insure that the judicial branch augments executive policy, laid out as early as 1951 in a Department of State Bulletin: "For the first time in history, restitution may be expected to continue for as long as works of art known to have been plundered during a war continue to be rediscovered."

The full scope of trafficking in Nazi-looted art through Switzerland and into the United States - including into some of our most esteemed institutions - is still to be discovered. ${ }^{158}$ A report by art historian Laurie A. Stein was published in the final report of the Bergier Commission, an independent commission of experts established by the Swiss Parliament to study the role of Switzerland in art trafficking during World War II. ${ }^{159}$ The Bergier Report came out in March 2002. ${ }^{160}$ Stein's report indicates that research to date has only scratched the surface of the "extraordinary breadth of traffic in art to the United States that was occurring in the Nazi era." 161 Stein stated that "the myths of American museum directors and collectors purchasing art in the 1930's through Swiss sources, in order to rescue it from the National Socialists, need to be reconsidered."162 She added: "It must be remembered that while

\footnotetext{
156. Id. at 152 .

157. Hall, supra note 1 , at 339 .

158. See generally Lucille A. Roussin, The Price of Pictures, 7 CARDOZO PUB. L. POL'Y \& ETHICS J. 709 (2009) (discussing the growth of the art market since WWII, the importance of caution and consequence in investigation and purchase of artwork, and the debate over restitution surrounding artwork looted from Jewish families).

159. Laurie A. Stein's name is found on page 571 of the report under the heading "Members, General Secretaries, Staff and Mandatees of the ICE.” FINAL REPORT, INDEP. COMM'N OF EXPERTS Switz., Switzerland, National Socialism AND the Second World War (2002), http://www.uek.ch/en/index.htm (follow "Reports 2001/2002" heading; then follow "Final report" subheading).

160. Id. at 36 .

161. Laurie A. Stein, The Path of Art from Switzerland to America from the Late 1930's to the early 1950's: A Report of Research Results, 2 (undated but commissioned for a 2002 report), http://www.scribd.com/doc/51566381/Stein-Pyritz-Swiss-Government-Report (last visited Sept. 16, 2012).

162. Id. at 3 .
} 
Europe went to war, America was still conducting business as usual, even in the cultural arena-defining new museum collecting policies, mounting exhibitions, and building private collections from the best possible art available on the market."163

The report focuses mostly on art channeled into American museums via Nazi sales of degenerate art taken from German museums and auctioned in Switzerland - as advertised in the popular New York publication Art News - to raise foreign currency. ${ }^{164}$ Some art-world insiders could not resist the temptation to scoop up a masterpiece for a bargain despite knowing that the net effect would be to "transform works of art into armaments." " 165 Many of those masterpieces were eventually sold or donated to American museums. ${ }^{166}$ The report fingers some wellknown institutions and people as having handled or ultimately received this art-MoMA, the Fogg Art Museum, Curt Valentin, "this country's most influential figure in the development of modern art," and Joseph Pulitzer, Jr., to name a few. ${ }^{167}$

One could read the report to support a hypothesis that the highprofile dealers and collectors who facilitated transactions to the named museums are likely many of the same individuals who trafficked looted Jewish-owned art in Switzerland. This hypothesis finds support in another book that discusses the trafficking of degenerate art through Switzerland, Stephanie Barron's "Degenerate Art": The Fate of the Avant-Garde in Nazi Germany, which states in relevant part:

\footnotetext{
163. Id.

164. Id. at 5 .

165. Id. at 15 .

166. See supra note 103 .

167. See Stein, supra note 161, at 9 (quoting art collector Morton May); see also Jane Wade Papers, Archives of American Art, Letter from Reich Chamber of Fine Arts to Curt Valentin, Re: Your letter of 22 September 1936 (Nov. 14, 1936), microformed on reel \#2322, frame 929 (July 1, 2002) (translation and original on file with author) ("The President of the Reich Chamber of Fine Arts instructed me to tell you that it would be of no objection to him if you make use of your connections with the German art circle and thereby establish supplementary export opportunities, if [this is done] outside Germany. Once you are in a foreign country, you are free to purchase works by German artists in Germany and make use of them in America.") (Swastika stamp after signature); Letter from Curt Valentin to Mrs. Dailey (July 23, 1948) (stating "Indescribable what became of Germany. I wish I would not have come. All bronzes by Matisse are cast in ten [sic] — and all are signed, and numbered. The one mentioned I pulled from under his own bed. I hope everything goes well with you. I hope the summer is fine. It's raining over here ever since I came, no matter in which country I am hunting Art and people.") (on file with author).
} 
On February 19 Fischer[, the Swiss gallery that conducted auctions for the Nazis to raise foreign currency,] had received the first inquiry from abroad: Curt Valentin, writing from America, must have known of the impending sale from colleagues in Berlin. He had emigrated from Germany the year before and opened a New York branch of Buchholz's gallery (Buchholz being one of the four German dealers authorized by the National Socialists to sell 'degenerate' art). Quickly establishing himself as the leading dealer in German Expressionist art in America, Valentin would indeed become one of the most important bidders at the auction. ${ }^{168}$

In sum, to highlight the breadth of the issue, Stein wrote: "The range and constancy of recently-arrived works being offered and acquired by Americans evidences that the United States became a welcoming homeland for confiscated and looted art, and Switzerland became probably the most important conduit country for the rush of American art collecting during the era." 169 According to Stein's report, "[i]t is clear that there was much more dealing between American-based buyers ... either in front of the auction block or behind the scenes, than has been recognized up until now." $" 170$

\section{Dismissal of Holocaust-ERA ART Claims Due to LaCK OF JUDICIAL NOTICE OF KEY HISTORICAL FACTS}

The recent wave of dismissals of Nazi-era art cases was grounded in three errors: (1) misapplication of the discovery rule triggering the statute of limitations; (2) insufficient reliance upon historical evidence and historians' expertise to understand the context of the claims; and (3) jurisdictional grounds-using that term a bit loosely-to include misinterpretation of the FSIA and federal preemption doctrine. ${ }^{171}$ The third reason is beyond the scope of this Article, but the other two are addressed below. All three errors have distorted the historical record by

168. Stephanie Barron, "Degenerate ArT": The Fate of the Avant-Garde in Nazi GERMANY 137 (Susan Caroselli, ed., 1991).

169. Stein, supra note 161 , at 37 .

170. Id. at 9 .

171. See Westfield v. Germany, No. 3:09-0204, 2009 WL 2356554, at *5 (M.D. Tenn. July 28, 2009) (ruling, without even citing the seminal Bernstein case, that Germany could not be sued under the FSIA for any taking of property during war), aff'd on other grounds by 633 F.3d 409 (6th Cir. 2011); Von Saher v. Norton Simon Museum of Art, 578 F.3d 1016 (9th Cir. 2009) (dismissing case under federal preemption principles). But see Cassirer v. Kingdom of Spain, 461 F. Supp. 2d 1157 (C.D. Cal. 2006) (properly holding that Spain is subject to jurisdiction under the FSIA for possessing Nazi-looted art), aff'd in part, rev'd in part, 580 F.3d 1048 (9th Cir. 2009), aff'd in part, appeal dismissed in part en banc, 616 F.3d 1019, 1037 (9th Cir. 2010), cert. denied 131 S. Ct. 3057 (2011). 
precluding inquiry into what truly happened to the paintings at issue. Erring courts implicitly made incorrect and improper factual interpretations to reach their premature legal conclusions.

\section{A. Misapplication of the Discovery Rule and Related Time-Bar Principles}

In essence, the constructive discovery rule provides that in certain cases the statute of limitations will not begin to run until the claimant has or should have knowledge of the claim and of the correct entity to sue. ${ }^{172}$ This rule "is highly fact specific and great discretion is left to judges to determine when to apply it."173 "Generally, both actual and constructive notice are factual questions, determined by a jury." 174 The constructive discovery rule has been applied in conversion and restitution cases throughout the United States with the following variants. ${ }^{175}$

First, New York is alone in following the "demand and refusal" rule in all conversion cases, which dictates that the limitations period begins to run only when the true owner demands the artwork's return from the current possessor and is refused. ${ }^{176}$ This rule may sound extreme, but it

172. See generally Lauren F. Redman, A Wakeup Call for a Uniform Statute of Limitations in Art Restitution Cases, 15 UCLA ENT. L. REV. 203 (2008) (discussing constructive discovery rule with respect to different state jurisdictions); Patricia Youngblood Reyhan, A Chaotic Palette: Conflict of Laws in Litigation Between Original Owners and Good-Faith Purchasers of Stolen Art, 50 DuKE L.J. 955, 1005 n.258 (2001) ("Where, as in this case, the parties either explicitly or by implication agree to be governed by the substantive law of the forum state, their agreement will be enforced." (citing Mucha v. King, 792 F.2d 602, 604 (7th Cir. 1986))); see also Dunbar v. SegerThomschitz (Seger-Thomschitz I), 638 F. Supp. 2d 659, 663 (E.D. La. 2009) ("The period for liberative prescription begins to toll when the claimant reasonably should have discovered the injury." (citation omitted)), aff'd, 615 F.3d 574 (5th Cir. 2010), cert. denied, 131 S. Ct. 1511 (2011).

173. Redman, supra note 172, at 219.

174. Schwartz v. Cincinnati Museum Assoc., 35 F. App'x 128, 131 (6th Cir. 2002) (citing Charash v. Oberlin College, 14 F.3d 291, 300 (6th Cir. 1994)). Coincidentally Oberlin College has refused to return a painting from the Grunbaum collection to the Grunbaum heirs. Raymond Dowd, Nazi Looted Art at Oberlin College and Other U.S. Museums: Prague Conference on Holocaust-Era Assets, ART StOlen From Fritz GRUNBAUM (Aug. 14, 2009), http://artstolenfromfritzgrunbaum. wordpress.com/tag/egon-schiele/.

175. See, e.g., Redman, supra note 172, at 219-20; Reyhan, supra note 173, at 1021. Claims may also be couched as quasi-contract or unjust enrichment. E.g., Dunbar v. Seger-Thomschitz (Seger-Thomschitz II), 615 F.3d 574, 576 (5th Cir. 2010), cert. denied, 131 S. Ct. 1511 (2011); see also Seger-Thomschitz I, 638 F. Supp. 2d, at 662 (discussing civil law "innominate real action" (citing 2 Yiannopoulos, Louisiana Civil LaW Treatise $§ 241,476$ (1991)); Museum of Fine Arts, Bos. v. Seger-Thomschitz (Seger-Thomschitz III), 623 F.3d 1, 3-14 (1st Cir. 2010) (mentioning constructive trust, restitution, unjust enrichment, injunctive relief and replevin)), cert. denied, $131 \mathrm{~S}$. Ct. 1612 (2011), reh'g denied, 131 S. Ct. 2176 (2011).

176. E.g., Solomon R. Guggenheim Found. v. Lubell, 569 N.E.2d 426, 429 (N.Y. 1991). 
is greatly tempered by the applicability of the laches defense, whereby a plaintiff's claim will be barred if the plaintiff unreasonably delayed in bringing the claim and such delay caused the defendant to suffer prejudice. ${ }^{177}$ Second, California law on this issue is muddled, ${ }^{178}$ especially because the constitutionality of statutes extending the limitations period in Holocaust-era cases have been struck down. ${ }^{179}$ Third, Louisiana follows civil law prescription principles. ${ }^{180}$ Fourth and finally, a wrong-headed Michigan case recently held the discovery rule did not apply at all, so that a claim to Nazi-looted art expired in $1938 .{ }^{181}$

Statutes of limitation exist to foster three primary goals: (1) to encourage plaintiffs to file suit promptly "on the premise that those with valid claims will not delay in asserting them"; ${ }^{182}$ (2) to promote "the free trade of goods, by making sure that those who have dealt with property in good faith can enjoy secure and peaceful possession after a certain, specified time period"; ${ }^{183}$ and (3) to protect defendants that may be

177. See id. at 430 .

178. See CAL. Civ. Proc. Code § 338(c) (West 2007); Orkin v. Taylor, 487 F.3d 734, 741 (9th Cir. 2007) (discussing California statute of limitations in Holocaust-era case), cert. denied 552 U.S. 990 (2007); Naftzger v. Am. Numismatic Soc'y, 49 Cal. Rptr. 2d 784, 786 (Cal. Ct. App. 1996); Soc'y of Cal. Pioneers v. Baker, 50 Cal. Rptr. 2d 865, 866 (Cal. Ct. App. 1996); Redman, supra note 172 , at 213 ("California has the most chaotic approach ....").

179. Am. Ins. Assoc. v. Garamendi, 539 U.S. 396, 409, 420 (2003) (finding that California statute requiring reporting of unpaid Holocaust-era insurance policies was preempted by treaty); see, e.g., Von Saher v. Norton Simon Museum of Art, 592 F.3d 954, 968 (9th Cir. 2010), cert. denied, 131 S. Ct. 3055 (2011) (striking down statute that would have authorized suits against museums and galleries); Deutsch v. Turner Corp., 324 F.3d 692, 709-12 (9th Cir. 2003) (slave labor claims preempted); Steinberg v. Int'l Comm'n on Holocaust Era Ins. Claims, 34 Cal. Reptr. 3d 944, 945 (Cal. Ct. App. 2005) (insurance claims preempted).

180. See Seger-Thomschitz II, 615 F.3d at 576 ("[O]wnership of the painting, which had been open and continuous for well over ten years, fulfill[s] the requirements to establish ownership by acquisitive prescription under Louisiana law.").

181. Detroit Inst. of Arts v. Ullin, No. 06-10333, 2007 WL 1016996, at *3 (E.D. Mich. Mar. 31, 2007).

182. Ralph E. Lerner, The Nazi Art Theft Problem and the Role of the Museum: A Proposed Solution to Disputes over Title, 31 N.Y.U. J. INT'L L. \& POL. 15, 17 (1998); see also Suzette M. Malveaux, Statutes of Limitations: A Policy Analysis in the Context of Reparations Litigation, 74 GeO. WASH. L. REV. 68, 80 (2005) (explaining that those with strong evidence would not delay); PALMER, supra note 82, at 54-55.

183. Lerner, supra note 182, at 17 (citing John G. Petrovich, The Recovery of Stolen Art: Of Paintings, Statues and Statutes of Limitations, 27 UCLA L. REV. 1122, 1127-28 (1980)). Additionally, the doctrine of adverse possession presents another nuance to the statute of limitations inquiry. E.g., Paulina McCarter Collins, Has "The Lost Museum” Been Found? Declassification of Government Documents and Report on Holocaust Assets Offer Real Opportunity to "Do Justice" for Holocaust Victims on the Issue of Nazi-Looted Art, 54 ME. L. REV. 115, 129-31 (2002) (illustrating adverse possession and open enjoyment of property); Patty Gerstenblith, The Adverse Possession of Personal Property, 37 BufF. L. REv. 119, 119 (1989) ("[T] he most important element required to establish adverse possession of personal property is the good faith and reasonable reliance of the 
prejudiced in defending claims because of the loss of evidence over time. $^{184}$ As demonstrated below, the recent wave of dismissals of Holocaust-era claims does nothing to further these goals.

\section{Dismissal of Holocaust-era Art Claims Does Not Encourage Prompt Filing of Complaints}

As for the first policy reason for statutes of limitations - that those with valid claims will act promptly-the courts are failing to recognize that many heirs are just now learning about their claims, or the ability to assert them with any chance of success. This is due in part because "[a]s governments release records, cases are filed which lead victims or their heirs to file more cases with the increasing public awareness putting pressure on governments to cooperate." 185 Many archives and records remained sealed until the mid-1990s or are still sealed; as information trickled out, many survivors knowledgeable about a family's wartime assets died. ${ }^{186}$

In such cases, it is quite possible that no one in the family remains with the requisite knowledge to put two and two together and claim a particular looted painting. It is not the case that the present-day claimants were fully informed about their claims but merely chose to do nothing about it for so long. ${ }^{187}$

adverse possessor.").

184. E.g., Am. Pipe \& Constr. Co. v. Utah, 414 U.S. 538, 554 (1974) (noting that "statutory limitation periods are designed to promote justice by preventing surprises through the revival of claims that have been allowed to slumber until evidence has been lost, memories have faded, and witnesses have disappeared." (citing Order of R.R. Telegraphers v. Ry. Express Agency, 321 U.S. 342, 348-49 (1944))); John H. Merryman, The Good Faith Acquisition of Stolen Art, Stanford Public Law Working Paper No. 1025515, Oct. 29, 2007, available at http://papers.ssrn.com/ sol3/papers.cfm?abstract_id=1025515 (last visited Aug. 26, 2012).

185. Redman, supra note 172, at 211.

186. For a good discussion of this problem for claimants of Holocaust-era art, see Leah J. Weiss, Note, The Role of Museums in Sustaining the Illicit Trade in Cultural Property, 25 CARDOzo ARTS \& ENT. L.J. 837, 866-69 (2007).

187. In many cases, it simply was not politically feasible to reclaim the art. Portrait of Wally involved facts that would have implicated a laches defense had it been brought for replevin rather than civil forfeiture. See Third Amended Verified Complaint 9 gg, United States v. Portrait of Wally, 663 F. Supp. 2d 232 (S.D.N.Y. 2009) (No. 99 Civ. 9940 (LAP), 2001 WL 34727703 (quoting handwritten note found upon victim's death: "I myself prevent a Court case with the Belvedere (Museum for Modern Art in Vienna) as I was reinstated as the proprietor of the Gallery Würthle, Gallery exclusive for Modern Art, and as this it was not possible for me to quarrel with the Museum of Modern Art and tried to get my picture back by peaceful means.").

The litigation was settled for the full value of the portrait in 2010. Press Release, U.S. Att'y Southern District of N.Y., U.S. Announces \$19 Million Settlement in Case of Painting Stolen by 
For example, one successful claimant who never would have recovered her property but for happenstance is Marie Altmann, the woman who claimed a number of masterpieces by Gustav Klimt in Austria and won them back - after her fight took her all the way to the Supreme Court. ${ }^{188}$ After the war, Altmann was still quite young and another family member on the continent, who hired an Austrian lawyer, handled the haggling with Austria for restitution. ${ }^{189}$ Generally, Jews seeking restitution from Austria immediately after the war did not enjoy much success. ${ }^{190}$ Because of the Austrian practice of extorting donations of Jews' property in exchange for restitution and export permits, the lawyer struck a deal-some recovery is better than no recovery in a system that actively discriminates against persecuted refugees. ${ }^{191}$ Altmann had no idea that she had a claim until the now-deceased journalist Hubertus Czernin sent her a package of historical documents he had unearthed. ${ }^{192}$ By that time, she was the last surviving heir of Ferdinand Bloch-Bauer, from whom everything was taken during the war. ${ }^{193}$

We lose historical knowledge as survivors pass away each day. A recent bill passed by California that requires a claimant's "actual discovery" to trigger the limitations period reflects this reality. ${ }^{194}$ The

Nazi (July 20, 2010), http://www.justice.gov/usao/nys/pressreleases/July10/portraitofwally settlementpr.pdf; Press Release, Herrick, Feinstein LLP, The U.S. of Am., the Estate of Lea Bondi Jaray and the Leopold Museum Settle the Long-Standing Case Involving "Portrait of Wally" by Egon Schiele, (July 20, 2010), http://info.herrick.com/rs/vm.ashx?ct=24F76A15D4AE4EE0CD D881AFD42F921E91907ABFDA9818CF5AE175767CEAC80BDF416. Other political persecutees have not been so fortunate. See, e.g., Letter from George Grosz to Oz (Jan. 8, 1953) (original on file at the Otto Schmalhausen Archives and translation on file with author) ("The Modern Museum exhibited a stolen picture of mine (I am powerless to do anything against it), they bought it from someone who stole it.").

188. See Republic of Austria v. Altmann, 541 U.S. 677 (2004).

189. Id. at 683 .

190. See id. at 682-83 (discussing the artwork export laws enacted in Austria in 1946).

191. Id. at 705. Other countries have similarly abysmal restitution records. See, e.g., István Fodor, The Restitution of Works of Art in Hungary, in THE SPOILS OF WAR, supra note 96, at 92-94; Pavel Jirásek, Losses of Cultural Property From the Territory of the Czech Republic Due to World War II, in THE SPOILS OF WAR, supra note 96, at 232-33; Jan P. Pruszyński, Poland: The War Losses, Cultural Heritage, and Cultural Legitimacy, in THE SPOILS OF WAR, supra note 96, at 4952.

192. See Grimes, supra note 61 ("In 1998, Ms. Altmann became aware of documents in the Austrian government archives uncovered by Hubertus Czernin, a journalist ....”).

193. Id.

194. A.B. 2765, 2010 Leg., ch. 691 (Cal. 2010); see also Sheppard Mullin, California AB 2765 Stops the Clock for Recovery of Wrongfully Appropriated Works: The Ramifications for Museums, Owners, Collectors and the Art Trade, ART LAW GALlery Blog (Oct. 11, 2010), 
California Association of Museums opposed the bill, claiming that the "actual knowledge" standard is "vague and subjective" and noting the "great lengths" to which museums go to insure that what they acquire has "solid legal title." 195 These statements provoke responses. First, the actual knowledge standard would be no more vague and subjective than the constructive discovery rule-currently in place throughout the country with relatively little variation. ${ }^{196}$ Second, as Part III demonstrates, the California Association of Museums' understanding of the term "great lengths" likely stops, as to many objects, far short of any honest concept of diligence. ${ }^{197}$ In fact, willful blindness had been the norm in the art world. ${ }^{198}$ This standard exists because "[w]hile art dealers protest that they are only protecting the desire of their wealthy clients to remain anonymous, and that they are under no legal duty to inquire into the sources of art work they trade, such anonymity removes illegitimate transactions from needed scrutiny."199 Unfortunately, the bill was struck down in Von Saher v. Norton Simon Museum of Art. ${ }^{200}$

\section{Dismissal of Holocaust-Era Art Claims Does Not Insure Free Trade and Secure Possession}

The second policy reason for statutes of limitations - promotion of free trade of goods - is largely premised on the concept of a good faith purchaser. Courts seem to presume that purchasers of Holocaust assets possessed good faith despite extraordinary evidence to the contrary. ${ }^{201}$ Perhaps the best example is Detroit Institute of Arts v. Ullin, in which the court ruled against the heirs of a Holocaust victim, deciding that the discovery rule did not apply because Michigan policy favors market

http://www.artlawgallery.com/2010/10/articles/museums-private-collectors/california-ab-2765stops-the-clock-for-recovery-of-wrongfully-appropriated-works-the-ramifications-for-museumsowners-collectors-and-the-art-trade/ (explaining the history and impact of the bill).

195. Letter from Barbara Long, et al., to Assemblymember Mike Feuer, Re: AB 2765 Civil

Actions: Statutes of Limitation: Theft, at 3, 6 (Aug. 19, 2010) (on file with author).

196. See supra notes 172-75 and accompanying text.

197. See supra Part III.B (discussing the acquisition of artworks by museums despite undeniable knowledge of the likelihood that those artworks were taken from Jews by force or duress).

198. E.g., Bakalar v. Vavra, 619 F.3d 136, 150 n.5 (2d Cir. 2010) (criticizing gallery owner who claimed "that to question a reputable dealer as to his title would be an "insult"'); Id. at 141 (noting "“art dealers' usual practice of not examining the sources of the art works in which they trade." (quoting Drum, supra note 153, at 912)).

199. Drum, supra note 153, at 912-13.

200. 592 F.3d 954, 968 (9th Cir. 2010), cert. denied, 131 S. Ct. 3055 (2011).

201. See infra Part IV.B. 
certainty in cases alleging commercial conversion. ${ }^{202}$ Almost unbelievably, the court expressly ruled that the claim accrued in 1938, meaning that the state's three-year statute of limitations expired in $1941^{203}$ - before the United States even landed on the beaches of Normandy and liberated survivors in death and work camps.

When determining whether to strictly enforce the three-year statute of limitations or apply the discovery rule, courts "must carefully balance when the plaintiff learned of her injuries, whether she was given a fair opportunity to bring her suit, and whether defendant's equitable interests would be unfairly prejudiced by tolling the statute of limitations." ${ }^{204}$ In Ullin, the court did not engage in this balancing test. ${ }^{205}$ Even though Mrs. Nathan, the original owner of the painting, was forced by the Nazis to sell six other paintings and move other property to Switzerland, the court did not discuss the possibility that the sale of the painting in question resulted from wartime duress. ${ }^{206}$ Not only did the court ignore the duress element, but it also did not address the fact that Nathan's heir denied that the sale of the painting even took place. ${ }^{207}$ Although she successfully sought restitution of other paintings after the war, Nathan did not seek to claim this painting, and her current claim was barred. ${ }^{208}$ Rather than obtain more facts about the transaction surrounding the painting, the court decided that even if the discovery rule were applicable, Nathan's heirs did not exercise due diligence. ${ }^{209}$

One scholar has explained why the market certainty rationale is inapposite to stolen art cases: "Where the law favors purchasers over owners, purchasers have little incentive to cautiously investigate an artwork's title. Even galleries and auction houses have an incentive to ignore suspicious circumstances. This is especially problematic in an area where theft is so rampant." 210

202 Detroit Inst. of Arts v. Ullin, No. 06-10333, 2007 WL 1016996, at *1, *3 (E.D. Mich. Mar. $31,2007)$.

203. Id. at *3.

204. Stephens v. Dixon, 536 N.W.2d 755, 757 (Mich. 1995).

205. See Ullin, 2007 WL 1016996.

206. See id.

207. See id. at $* 2$ n. 3 .

208. Id. at $* 2-4$.

209. Id. at *3.

210. Redman, supra note 172, at 212 (footnotes omitted). Moreover, purchasers' claims against middlemen, such as breach of warranty, run from the date of purchase. See Doss, Inc. v. Christie's Inc., No. 08 Civ. 10577 (LAP), 2009 WL 3053713, at *2-3 (S.D.N.Y. Sept. 23, 2009) (holding that plaintiff's cause of action accrued when plaintiff bought a painting from defendant auctioneer that 


\section{Dismissal of Holocaust-Era Art Claims Unduly Protects Defendants from Loss of Evidence Over Time}

Courts heavily emphasize the third policy reason for statutes of limitations - protection of defendants - in Holocaust-era cases. For example, the United States District Court for the District of Massachusetts granted the Boston Museum of Fine Arts' summary judgment motion on statute of limitations grounds in a declaratory judgment action filed against Dr. Seger-Thomschitz, heir of Dr. Oskar Reichel. ${ }^{211}$ Dr. Reichel was a Jewish doctor, art collector, and owner of a Viennese gallery, which was moved out of Vienna in February 1939, well after the Anschluss of Austria, and after he was forced to submit property declarations to the Viennese Nazis, including the Oskar Kokoschka painting in question, Two Nudes (Lovers). ${ }^{212}$ The court characterized the loss of the painting innocuously, as its having been "transferred to" an art dealer in Paris for sale. ${ }^{213}$

The art dealer was Otto Kallir-Nirenstein (known as Otto Kallir), the most influential dealer on modern art collectors in the United States. ${ }^{214}$ Shortly after the Anschluss, Kallir transferred his own Vienna gallery to his non-Jewish secretary, ${ }^{215}$ opened the Galerie St. Etienne in Paris, and moved to the United States in August of 1939 to open the New York branch of Galerie St. Etienne, to include the painting and other works. ${ }^{216}$ Alfred Barr, MoMA Chairman, helped sponsor Kallir's immigration. ${ }^{217}$ Barr wrote a letter characterizing Kallir as a destitute, broken man, ${ }^{218}$

\footnotetext{
was subsequently discovered to have been stolen).

211. Museum of Fine Arts, Bos. v. Seger-Thomschitz (Seger-Thomschitz IV), Civil Action No. 08-10097-RWZ, 2009 WL 6506658, at*1, *11 (D. Mass. June 12, 2009), aff'd, 623 F.3d 1 (1st Cir. 2010), cert. denied, 131 S. Ct. 1612 (2011), reh'g denied, 131 S. Ct. 2176 (2011).

212. Id. at *1-2.

213. Id. at $* 7$.

214. Id. at $* 1$

215. See id. at $* 2$. This was a typical practice that Jews were forced to undergo in attempts to protect their property from Nazi-confiscation. See DEAN, supra note 109, at 65. But, questions have been raised whether Kallir was persecuted - or whether he was persecuted and later made a deal with the Nazis to broker transactions to bring them foreign currency.

216. Seger-Thomschitz IV, 2009 WL 6506658, at *2.

217. Letter from Alfred H. Barr, Jr., Director, The Museum of Modern Art, to Mr. Correa (June 30,1942 ) (on file with author) ("This letter is to testify to the loyalty to the United States of an alien, Mr. Curt Valentin, now in this country. Mr. Valentin is a refugee from the Nazis both because of Jewish extraction and because of his affiliation with free art movements banned by Hitler. He came to this country in 1937, robbed by the Nazis of virtually all possessions and funds.").
}

218. Id 
which is inconsistent with his ability to maintain such an active art trade during the war.

Kallir's name has been central to a number of the recently filed cases, as historians explore newly accessed documents, causing some to question his prior reputation as a white knight to fleeing Jews whose art was liquidated. ${ }^{219}$ The defendant museum submitted letters to the court, which had been written in the 1980s by one of Dr. Reichel's sons, Raimund, to art historians independently researching Kokoschka's work. ${ }^{220}$ Dr. Seger-Thomschitz argued that the letters indicate that Kallir had told Raimund that Dr. Reichel entrusted the paintings to him in 1938, perhaps even before the Anschluss. ${ }^{221}$

Dr. Seger-Thomschitz argued that the correct interpretation of the letters - one of which states that Kallir said that he "lost his shirt" in the Kokoschka deal ${ }^{222}$-is that Raimund was misled into accepting a nominal $\$ 250$ for the painting by Kallir's misrepresentation as a persecutee, rather than a collaborator. ${ }^{223}$ Dr. Seger-Thomschitz prayed for the court to toll the statute of limitations on various grounds, including that Kallir, and then the museum, had engaged in fraudulent concealment. $^{224}$ In essence, Dr. Seger-Thomschitz's theory was that a number of Jewish dealers trafficking during the war purported to be persecutees, which the museums that accepted art from those dealers knew was false. Consequently, the museums have unclean hands and thus should be estopped from asserting the statute of limitations. The court rejected her argument and found that there was "no evidence of bad faith, laches or unclean hands" on the museum's part. ${ }^{225}$

The court noted that, because the alleged illegitimacy of the transfer to Kallir was "not clear-cut, and all of the witnesses with first-hand knowledge of the transfer are now deceased," the museum did not act in bad faith. ${ }^{226}$ Incredibly, the court provided as its sole justification for its holding the fact that "[o]ther museums faced with similar claims in

\footnotetext{
219. See Jason Horowitz, Dealer With the Devil, N.Y. OBSERVER, Sept. 11, 2007, at 2, http://www.observer.com/2007/09/dealer-with-the-devil/ (suggesting that recent litigation "blows a hole" in Kallir's reputation).

220. Seger-Thomschitz IV, 2009 WL 6506658 at *2-3.

221. Id. at *3.

222. Id. (quoting 1985 letter).

223. See id. at *4 (arguing the transfer was "forced").

224. Id. at $* 10$.

225. Id. at *6.

226. Id.
} 
which the circumstances of a wartime transfer made the legitimacy of the transfer debatable have also refused to summarily return the artworks and, instead, sought declaratory judgments of ownership."227 These facts demonstrate merely that many venerated American museums have convinced courts that the museums acted in good faith.

The court also faulted Dr. Seger-Thomschitz for failing to obtain the same information the museum had, stating that she "had the same opportunity to obtain this evidence." ${ }^{228}$ This is not true. Even when claimants have sought judicial assistance in discovery to support Holocaust-era claims, they have been denied. ${ }^{229}$ Regardless of the merits of this particular case, it is ludicrous to suggest that any single person would have the same contacts and influence as one of the most prominent museums in the country to convince third parties to voluntarily produce information. The court granted the museum's summary judgment motion, which demands a standard much higher than plausibility - that "no genuine issue of material fact" exists. ${ }^{230}$ Is it plausible that the court drew all reasonable inferences in favor of Dr. Seger-Thomschitz, as it was required to do $?^{231}$ Dismissal of the case shut down an avenue to compel production of documents relevant to this question from the museum and third parties who may have them-and consequently, the pursuit of truth and memory.

Moreover, the court effectively found that Dr. Seger-Thomschitz was insufficiently diligent to prevent a finding that the discovery rule triggered the statute of limitations to run before the case was filed. ${ }^{232}$ Kallir sold the Kokoschka to another gallery in 1945, which transferred it

$$
\begin{aligned}
& \text { 227. Id. } \\
& \text { 228. Id. at } * 10 \text {. }
\end{aligned}
$$

229. See, e.g., In re Peters, 34 A.D.3d 29, 38-39 (N.Y. App. Div. 2006) (denying request under New York's pre-action disclosure law to force identification of anonymous purchaser of painting claimed to be Nazi-looted art on limitations grounds). But see In re Alexander, 33 A.D.3d 411, 412 (N.Y. App. Div. 2006) (ordering gallery to reveal name of buyer of stolen sculpture).

230. FED. R. CIV. P. 56(c).

231. See Matsushita Elec. Indus. Co. v. Zenith Radio Corp., 475 U.S. 574, 588 (1984); United States v. Diebold, Inc., 369 U.S. 654, 655 (1962) (“On summary judgment the inferences to be drawn from the underlying facts ... must be viewed in the light most favorable to the party opposing the motion.").

232. Seger-Thomschitz IV, 2009 WL 6506658, at *9. This is true despite the common understanding that only New Jersey applies a due diligence requirement to the discovery rule in art cases. See Bert Demarsin, The Third Time is Not Always a Charm: The Troublesome Legacy of a Dutch Art Dealer: The Limitation and Act of State Defenses in Looted Art Cases, 28 CARDOZO ARTS \& ENT. L.J. 255, 264-68 (2010) (the "discovery rule" is an "equitable approach that provide[s] an alternative to the uncomfortable confines of the traditional adverse possession analysis."); accord O'Keeffe v. Snyder, 416 A.2d 862 (N.J. 1980). 
to still another gallery. ${ }^{233}$ There it was purchased by Sarah Reed Blodgett between December 1947 and April 1948, who bequeathed it to the museum in $1972 . .^{234}$ The court concluded that certain "easily discoverable" facts would have put the family on notice of its claim long ago. $^{235}$ For instance, over the years, the spectacular painting has been included in a number of exhibitions across the United States and the catalogue for at least one of those exhibitions lists Dr. Reichel as a prior owner; it has been included in three catalogue raisonnés ${ }^{236}$ of Kokoschka's works; at least two of those listed Dr. Reichel as the prior owner; other publications have mentioned the work and Dr. Reichel's prior ownership; the museum has utilized the painting in advertising and other publications; the museum has listed the painting's provenance since December 2000 on its website; the Getty Provenance Index has included the painting's provenance since the late $1980 \mathrm{~s} ;{ }^{237}$ and a book published in Vienna in 2003 included a picture of the painting, the provenance, and the Reichel Nazi-era property declaration. ${ }^{238}$

Dr. Seger-Thomschitz argued that it is excusable that Raimund, in pursuing post-war restitution, did not know of his father's claims to the Kokoschka paintings because of the family's diaspora resulting from Nazi persecution, including the murder of one of Dr. Reichel's sons around $1940 .^{239}$ Another son, Hans, fled Austria by June $1938 .^{240}$ Raimund also fled in 1938. ${ }^{241}$ In November 1938, Dr. Reichel's art gallery, including its paintings, which were mostly by Romako, was liquidated because of his Jewish heritage. ${ }^{242}$ The family's apartment house was liquidated in 1941. ${ }^{243}$ In January 1943, Dr. Reichel's wife, Malvine, was deported to Therensiestadt, where she survived the war and eventually joined Hans in the United States. ${ }^{244}$

\footnotetext{
233. Seger-Thomschitz IV, 2009 WL 6506658, at *3.

234. Id. The museum's formal acquisition was complete in 1973.

235. Id. at *7, *9.

236. Id. at *4 n.4 (citing DeWeerth v. Baldinger, 836 F.2d 103, 112 (2d Cir. 1987)) (stating that, "a catalogue raisonné is a comprehensive catalog of artworks by an artist").

237. Id. at $* 2$.

238. Id. at *9.

239. Answer and Counterclaim - 46, Seger-Thomschitz IV, 2009 WL 6506658 (D. Mass. June 12, 2009) (No. 08-10097), 2008 WL 8416218.

240. Id. ๆ 82.

241. Id. ๆ 46.

242. Id. $\mid 35$.

243. Id. ๆ 37.

244. Id. 946.
} 
The brothers' post-war restitution application included a notarized statement by Raimund asserting that "[a] large art collection [owned by my father] was sold by force: 47 pictures by the painter Anton Romako." ${ }^{245} \mathrm{He}$ did not mention the Kokoschka paintings, ${ }^{246}$ but Dr. Reichel died after his wife was deported, leaving his sons with only their own recollections to rely on; they would not have known about the Kokoschka paintings due to their lack of access to the Austrian records that contained Dr. Reichel's property declaration - at least until the records were first made public in $1993 .^{247}$ By that time, presumably, they were no longer actively seeking restitution of property - they had gotten back what they could and moved on.

Dr. Seger-Thomschitz herself was actually put on notice to investigate any remaining claims of Reichel's heirs when the Vienna Community Council for Culture and Science contacted her in late 2003, following its own more-recent review of Viennese public collections. ${ }^{248}$ The court determined that this was the moment that the limitations period began to run based on Massachusetts's discovery rule. ${ }^{249}$ The Council's letter stated that Vita Künstler, whom Kallir had appointed as director of his Vienna gallery, had delivered the Romako paintings, which had been listed on the Reichel property declaration and for which compensation to Dr. Reichel was placed into a blocked account. ${ }^{250}$ The Council concluded: "It is certain that these paintings involved art objects from the property of Dr. Oskar Reichel and which, in connection with the power seizure by National Socialism, he had to sell due to his persecution as a Jew to the galleries mentioned...."251 Dr. Seger-Thomschitz argued that the path of the Romako paintings likely mirrored that of the Kokoschkas. ${ }^{252}$ However, the Answer and Counterclaim does not clearly allege that the proceeds of the sale of the Kokoschkas, if any, actually

\footnotetext{
245. Id. ๆ 20 (internal quotation marks omitted).

246. See id.

247. Id. 9 | $85-90$

248. Id.

249. Seger-Thomschitz IV, 2009 WL 6506658, at *9.

250. The First Amended Answer and Counterclaim also states that "once the Painting was placed on Dr. Reichel's Property Declaration - which the Nazis required all Jews to file-the Painting was effectively confiscated and owned by the Nazi state." First Amended Answer and Counterclaim - 13, Seger-Thomschitz IV, 2009 WL 6506658 (No. 08-10097), 2008 WL 8416219. Such an argument could give legal force to Nazi confiscation policy. The fact that Dr. Reichel had to list the painting may be a relevant factor in determining whether the sale actually was a farce, yet it should not be determinative of his ability to legally transfer title.

251. Id. at 2 exhibit 1.

252. Id.
} 
went into a blocked account. ${ }^{253}$ This is probably missing because she cannot locate any documents to justify the allegation without the power of court-mandated discovery behind her. Under Rule 11(b)(3), parties are prohibited from making factual contentions to a court unless they "have evidentiary support or, if specifically so identified, will likely have evidentiary support after a reasonable opportunity for further investigation or discovery." 254

Dr. Seger-Thomschitz was also sued in a declaratory action filed in the United States District Court for the Eastern District of Louisiana by the current holder of Portrait of a Youth (Hans Reichel), another painting by Kokoschka. ${ }^{255}$ The facts are similar. The Fifth Circuit ruled, on August 20, 2010, that the issues raised on appeal were not preserved below and thus could not be addressed, but noted: "Significantly, those members of the Reichel family with direct knowledge of the painting's sale never sought its return. ${ }^{256}$ The district court granted the present-day collector's summary judgment motion on the grounds of Louisiana's acquisitive prescription doctrine. ${ }^{257}$ The court found that, under the doctrine, the collector's ownership was open and continuous because the collector "displayed the painting in her home, and Plaintiff loaned the painting for exhibitions at local and national galleries, further publicizing its location and its ownership." ${ }^{258}$ The opinion provides no other details concerning the level of public knowledge about the painting, but, again, it misses the mark as to what would be reasonable for Holocaust survivors and their heirs who lost property to do.

It was unforeseeable to the average person before the mid-1990s that the archives would be opened and some records published, more than fifty years after the Jews' persecution. At what point - after seeking some post-war restitution and reaching the point of futility-could survivors and heirs justifiably conclude that no more restitution was

253. Answer and Counterclaim, supra note 239, 9 4 (“Indeed, in Dr. Reichel's case in particular, preceding sales proceeds for his artworks had been placed in 'blocked' accounts accessible only to the Nazis. Upon information and belief, even if Kallir[] had made any payment to Dr. Reichel, the money would have ended up in a 'blocked' account and in exclusive Nazi hands."); see also id. ๆๆ 52,81 .

254. FED. R. CIV. P. 11(b)(3).

255. Seger-Thomschitz I, 638 F. Supp. 2d 659, 661 (E.D. La. 2009), aff'd, 615 F.3d 574 (5th Cir. 2010), cert. denied, 131 S. Ct. 1511 (2011).

256. Seger-Thomschitz II, 615 F.3d 574, 576 (5th Cir. 2010), cert. denied, 131 S. Ct. 1511 (2011).

257. Seger-Thomschitz I, 638 F. Supp. 2d at 663.

258. Id. 
possible? Moreover, the district court announced a due diligence requirement whereby Holocaust victims and their heirs will be barred unless, since the war, they successfully placed advertisements in publications and actively hunted down their art collections. ${ }^{259}$ The court took no notice that only one jurisdiction in the country has imposed a due diligence requirement of any type on art recovery claimants. ${ }^{260}$ One wonders how many refugees had the funds in the post-war, pre-internet environment to finance such a potentially endless, fruitless hunt for assets on multiple continents. ${ }^{261}$ There were a few refugees and heirs, with thorough knowledge and documentation of their extensive art collections, who were able to continue confronting the past to track down their property beyond the immediate post-war period, but that number was low. ${ }^{262}$ Furthermore, once those heirs who had direct knowledge of art collections passed away, there was not necessarily anyone left with the requisite knowledge to conduct a search. As discussed above, heirs, such as Dr. Seger-Thomschitz, are learning about their claims today by happenstance. $^{263}$

Sadly, one federal court has used the fact that Congress conducted hearings in 1998 into wartime trafficking and the failure of post-war restitution against an heir, holding that public knowledge of the issue would have put a reasonable person on notice to investigate possible claims if members of her family were victims or survivors. ${ }^{264}$ In Toledo Museum of Art v. Ullin, the United States District Court for the Northern District of Ohio granted a motion to dismiss the claim of the heirs of Martha Nathan in a declaratory judgment action filed by the Toledo

259. Id. at 663-64.

260. See O’Keeffe v. Snyder, 416 A.2d 862, 876 (N.J. 1980) (requiring consideration of the claimant's actions toward recovering the stolen artifact). The Seger-Thomschitz I court correctly cited O'Keeffe to support adopting a novel legal standard, which it failed to recognize as such. Seger-Thomschitz I, 638 F. Supp. 2d at 663. It also cited an inapposite case, Autocephalous GreekOrthodox Church of Cypress v. Goldberg \& Feldman Fine Arts, Inc., 917 F.2d 278, 283 (7th Cir. 1990).

261. See, e.g., Vineberg v. Bissonnette, 548 F.3d 50, 53 (1st Cir. 2008) (involving a claimant who had actively sought artworks after the war).

262. In addition to the estate in Vineberg, the heirs to the Goudsticker and Herzog collections managed to actively search after the war with varying degrees of success resulting from their decades of efforts. Carol Vogel, An Art Trove, Looted by the Nazis and Recovered, is Going on Sale-Culture-International Herald Tribune, N.Y. TIMES, Feb. 22, 2007, http:/www.nytimes.com/ 2007/02/21/arts/21iht-heir.4677497.html?pagewanted=2; Complaint at 1, de Csepel v. Republic of Hungary, 808 F. Supp. 2d 113 (D.D.C. 2011) (No. 10-1261), 2010 WL 2940163, at *1.

263. See supra Part IV.A.3.

264. Toledo Museum of Art v. Ullin, 477 F. Supp. 2d 802, 807-08 (N.D. Ohio 2006). 
Museum of Art. ${ }^{265}$ The museum convinced the court to foreclose the claim, although Nathan fled Germany in $1938 .^{266}$ She returned to Germany briefly in 1939 and was forced to sell some art; the painting in question, Street Scene in Tahiti, was not among those paintings because it had been shipped previously to Switzerland. ${ }^{267}$ Some of her other property was shipped to France and later expropriated after the Nazi occupation. $^{268}$ In December 1938, before the German occupation of France, Nathan sold some of her artwork, including the painting in question, for $\$ 6,900$ in Switzerland to three Jewish art dealers-Justin Thannhauser, Alexander Ball, and George Wildenstein. ${ }^{269}$

Implicit in the court's decision is a characterization of the sale as fair, which constitutes an improper finding of fact on a motion to dismiss: "In short, this sale occurred outside Germany by and between private individuals who were familiar with each other. The Painting was not confiscated or looted by the Nazis; the sale was not at the direction of, nor did the proceeds benefit, the Nazi regime." ${ }^{270}$ This finding implies that the Nazis' reach was limited to the borders of the Reich, which is not true. As recently recognized by the Second Circuit, the Nazis pressured Jews to transfer property located outside the Reich in exchange for safety for themselves or others. ${ }^{271}$ The Second Circuit stated: "Of particular significance is the ordinance dated April 26, 1938, which required Jews to register their assets and which covered both those who sought to leave the Reich ... and those who remained, with the Reich seeking to appropriate their domestically as well as their externally held assets." 272

Just a few months after the dealers purchased Nathan's painting in Switzerland, in May of 1939, the Toledo Museum of Art purchased the painting for $\$ 25,000^{273}$ - just as the Nazis were preparing to invade

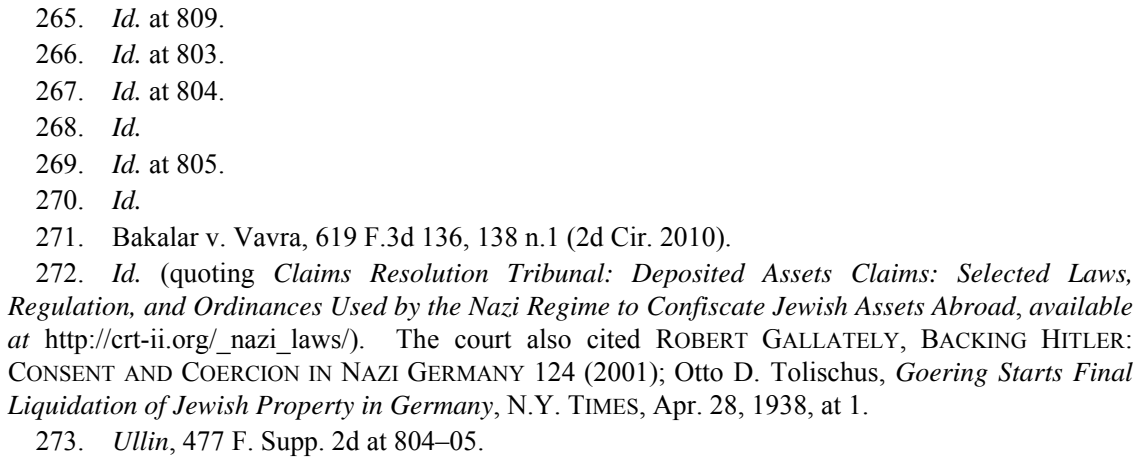
Regulation, and Ordinances Used by the Nazi Regime to Confiscate Jewish Assets Abroad, available at http://crt-ii.org/_nazi_laws/). The court also cited ROBERT GALlATELY, BACKING HiTLER: CONSENT AND COERCION IN NAZI GERmany 124 (2001); Otto D. Tolischus, Goering Starts Final Liquidation of Jewish Property in Germany, N.Y. TIMES, Apr. 28, 1938, at 1.

273. Ullin, 477 F. Supp. 2d at 804-05. 
Poland in September. ${ }^{274}$ The Ullin court faulted the Nathan heirs for not seeking restitution earlier because the museum "has had the Painting on display in Ohio and internationally since 1939 with Martha Nathan noted as prior owner." 275 Thus, the court concluded that the heirs were less than diligent. ${ }^{276}$ The judge might have unconsciously acted on a bias that a Jew would not have been forced to sell to a Jewish art dealer.

Another declaratory judgment action, filed by the MoMA and the Guggenheim, sought to shut down the claims of Julius Schoeps, heir to Paul Mendelssohn-Bartholdy, for paintings that passed through Thannhauser's hands. ${ }^{277}$ The museums alleged that it is simply implausible and contrary to common sense to suggest that any Jewish art dealer would take advantage of a fellow Jew. ${ }^{278}$ Some surely acted honorably as an act of solidarity, ${ }^{279}$ but it is likely that a few who were successful during the Reich, perhaps including Thannhauser as alleged in Museum of Modern Art v. Schoeps ${ }^{280}$ did not. The fact that these Jews may have been later persecuted when the Nazis no longer had a need for them does not discount the possibility that they trafficked in looted art. Schoeps settled on the eve of trial, ${ }^{281}$ which should teach us a lesson

274. See Otto D. Tolischus, Hitler to Inspect Western Defenses, N.Y. TimEs, May 14, 1939, at 22 (stating that Germany counters British encirclement policy by confirming the strength of and expanding its alliances and military); Guido Enderis, Nazis Say Axis Tie Will Be Unlimited, N.Y. TIMES, May 9, 1939, at 8 (stating that Germany and Italy formalize their military alliance in the face of encirclement powers and doubt of Axis powers).

275. Ullin, 477 F. Supp. $2 \mathrm{~d}$ at $805,807-08$.

276. See id. at 807-08 ("These inquiries and ordinary diligence would have revealed the sale of the Painting in 1938. Certainly by 1998, at the latest, Defendants had sufficient notice to alert them to the possibility of wrongdoing surrounding the Painting.").

277. Complaint for Declaratory Relief $9 \uparrow 1$ 1-4, Museum of Modern Art v. Schoeps, 549 F. Supp. 2d 543 (S.D.N.Y. 2008) (No. 07 Civ. 11074 (JSR)), 2007 WL 5161566.

278. Id. $\uparrow 2$.

279. See Dempsey, supra note 152 ("There is the issue of enforced transactions of every sale of every Jewish collection that happened during the Nazi times," said [Sean] Rainbird, a former curator of the Tate Modern in London. "There were cases where individuals were allowed to take their collections out of the country, and there were some dealers, in a gesture of solidarity, who helped them and were dealing with them in an honest way.").

280. According to Schoeps' Answer and Counterclaim:

Thannhauser trafficked in stolen and Nazi-looted art during his career as a dealer. Both during and after World War II, Thannhauser partnered with art dealers such as Nazi Cesar Mange de Hauke and Albert Skira, both of whom the U.S. State Department and others identified as traffickers in Nazi-looted art.

Answer and Counterclaim 40, Museum of Modern Art v. Schoeps, 549 F. Supp. 2 d 543 (S.D.N.Y. 2008) (No. 07 Civ. 11074 (JSR)), 2008 WL 1982812 (citing Maureen Goggin \& Walter V. Robinson, Murky Histories Cloud Some Local Art, Boston Globe, Nov. 9, 1997, at A1).

281. Christine Kearney, NY Museums Settle in Claim of Nazi-looted Picassos, ReuTERS (Feb. 2, 2009, 11:24 PM), http://in.reuters.com/article/idINIndia-37796820090202. 
about what can happen in these cases when judges do not let their biases cloud their views of what is plausible, and let cases proceed.

\section{B. Improperly Granting Motions to Dismiss Prevents Discovery of Historical Facts Necessary to Develop Claims}

One court has gone so far as to dismiss a claim, in 2010, on the grounds that the Plaintiff missed the statute of limitations by just three months. Grosz v. Museum of Modern Art ${ }^{282}$ was dismissed on the improper and incorrect theory that settlement communications triggered the limitations period under New York's "demand and refusal" rule ${ }^{283}$ despite the mandate of Federal Rule of Evidence 408 that such evidence may be used to "negat[e] a contention of undue delay." 284 The court also made other improper factual conclusions. ${ }^{285}$

"In this case, a German modernist artist later deemed to be an 'enemy of the State,' [George Grosz], fled Germany in January 1933, leaving his work with Jewish art dealer Alfred Flechtheim. Later, Flechtheim also fled. The Nazis aryanized Flechtheim's galleries in November 1933." "286 The museum acquired the works Grosz left with Flechtheim, Portrait of the Poet Max Herrmann-Neisse (with Cognac) (Poet), Self-Portrait with Model (Model) and Republican Automatons, in 1952, 1954, and 1946, respectively. ${ }^{287}$

282. 772 F. Supp. 2d 473 (S.D.N.Y.), aff'd, 403 F. App’x 575 (2d Cir. 2010), cert. denied, 132 S. Ct. $102(2011)$

283. Id. at 483

284. FED R. EVID. 408

285. The disputed issues of facts include: whether or not MoMA refused the Grosz Heirs' claims prior to April 12, 2006; whether or not Lowry was authorized by MoMA's Board of Trustees to issue a refusal prior to April 12, 2006; whether or not the Lowry Letter to Jentsch was an inadmissible settlement communication; whether or not Jentsch understood the Lowry Letter to be a refusal, and even if he did, whether it was within the scope of Jentsch's apparent authority to be notified of a refusal where the facts show that Lowry was in direct communication with the Grosz Heirs and Jentsch was not an attorney; and whether or not Lowry's claims that he had no authority to refuse the Grosz Heirs' claims, together with MoMA's June 26, 2008, letter confirming that a refusal took place on April 12, 2006, lulled the Grosz Heirs into believing that the statute of limitations would expire on April 12, 2006, and whether the Grosz Heirs' reliance on MoMA's representations was reasonable, warranting estoppel. Brief and Special Appendix for Plaintiffs-Appellants at 4, 17, 22, 29, 38-39, Grosz v. Museum of Modern Art, 403 Fed. App'x 575 (2d Cir. 2010) (No. 10-257cv), 2010 WL 2648161.

286. Brief for Am. Jewish Congress, Comm'n for Art Recovery et al. as Amici Curiae Supporting Plaintiffs-Appellants and Reversal at 23, Grosz, 403 F. App'x 575 (No. 10-257-cv), 2010 WL 2601991 (footnote omitted).

287. Brief and Special Appendix, supra note 285, at 15. 
First, Judge McMahon of the United States District Court of the Southern District of New York improperly found that the statute of limitations began to run during settlement negotiations and prior to MoMA's refusal letter of April 12, 2006. ${ }^{288}$ Under New York law, a cause of action accrues against a bona fide purchaser, and thus the statute of limitations begins to run, "when the purchaser refuses to return the property in question." 289 A refusal need only "convey[] an intent to interfere with the demander's possession or use of his property." 290 The district court based its ultimate conclusion on this point, isolating snippets of ongoing written and oral communications between Glenn Lowry, MoMA's Director, and Ralph Jentsch, an art historian hired by the Groszes to research their claims. ${ }^{291}$ Lowry repeatedly stated that he did not have authority to resolve the Grosz claim until the MoMA Board of Trustees could vote to adopt a report on the claim from an internal investigation conducted by Nicholas Katzenbach, who was not a provenance researcher, but rather served as U.S. Attorney General during the Lyndon B. Johnson administration. ${ }^{292}$ For example, in a January 18 , 2006, letter Lowry wrote: "As I have told you many times, including at our meeting in early January, any decision on a matter like this must be considered by the Museum's Trustees. ${ }^{293}$ Lowry on April 12, 2006, sent Jentsch a letter stating that Katzenbach completed his report, which recommended that the claim be denied, and that the "Museum's Board of Trustees has unanimously decided to accept Mr. Katzenbach's report and to abide by its findings." ${ }^{294}$ It is worth noting that Katzenbach's report is based solely on his assessment of the applicable statute of limitations ${ }^{295}$ - not on the factual truth of Nazi looting as called for by AAMD Guidelines, the Washington Principles, and the Terezín

\footnotetext{
288. Grosz, 772 F. Supp. 2d at 483-84.

289. Id. at 482 (citing Kunstsammlungen Zu Weimar v. Elicofon, 678 F.2d 1150, 1161 (2d Cir. 1982)).

290. Id. at 483 (emphasis omitted) (quoting Feld v. Feld, 720 N.Y.S.2d 35 (N.Y. App. Div. 2001) (internal quotation marks omitted).

291. See id. at $485-88$.

292. Id.

293. Brief for Am. Jewish Congress et al. as Amici Curiae Supporting Plaintiffs-Appellants and Reversal, supra note 286, at a-26 app.F, available at http://papers.ssrn.com/sol3/papers.cfm? abstract_id $=1628670$.

294. Id. at a-26 app.F.

295. Minutes of Meeting of the MoMA Bd. of Trs. at 2 (April 11, 2006) (on file with author).
} 
Declaration. In 2008, MoMA sent a letter to Grosz's recently hired counsel reconfirming the refusal date of April 12, $2006 .^{296}$

This dismissal was improper. Under Rule 9(f) of the Federal Rules of Civil Procedure, a motion to dismiss on limitations grounds is appropriate only when the material averments of time and place in the complaint demonstrate that the claim is time-barred. ${ }^{297}$ Further, courts may not determine contested facts concerning when a statute of limitations began to run on a motion to dismiss, ${ }^{298}$ and such a determination is inappropriate before discovery begins on the issue. ${ }^{299}$ Judge McMahon herself referred to Lowry's words as "temporizing language [that] was almost certainly designed to entice plaintiffs to continue negotiating and to prevent the dispute from becoming public or escalating into litigation." $" 300$ Thus, even had the limitations period run, Lowry's "temporizing language" calls for application of the equitable doctrines of tolling and estoppel. ${ }^{301}$

Second, the court made other erroneous and improper factual conclusions. The district court wrongly suggested in ruling on this motion to dismiss that the reason why Flechtheim went out of business was that he was in general financial distress, a distortion of the historical

296. Letter from Henry A. Lanman, Assoc. Gen. Counsel of MoMA, to attorney David J. Rowland (June 26, 2008) (on file with author).

297. See Matthew v. United States, 452 F. Supp. 2d 433, 446 (S.D.N.Y. 2006) (explaining that Rule 9(f) permits consideration of allegations of time and place and is used as a screening device permitting dismissal under Rule 12(b)(6) where the averments in the complaint make clear the claim is time-barred); Gossand v. Gossand, 149 F.2d 111, 113 (10th Cir. 1945); accord Santana-Castro v. Toledo-Davila, 579 F.3d 109, 113-14 (1st Cir. 2009); Bethal v. Jendoco Constr. Corp., 570 F.2d 1168, 1174 (3d Cir. 1978); Herron v. Herron, 255 F.2d 589, 593 (5th Cir. 1958).

298. See, e.g., Staehr v. Hartford Fin. Servs. Grp., 547 F.3d 406, 425 (2d Cir. 2008) (explaining that the lapse of a limitations period is an affirmative defense that the defendant may raise in a "12(b)(6) motion if the defense appears on the face of the complaint." (emphasis added)).

299. See id. It should be noted that in the letters Lowry offered potential shared ownership of one painting - even to withdraw MoMA's ownership claims. Grosz v. Museum of Modern Art, 772 F. Supp. 2d 473, 486 (S.D.N.Y.) ("In the spirit of friendship and recognition of the limitations on the present state of our knowledge about the provenance of the work, I suggested the possibility of shared ownership of [Poet] at our May 31 meeting."), aff'd, 403 F. App'x 575 (2d Cir. 2010), cert. denied, 132 S. Ct. 102 (2011).

300. Grosz, 772 F. Supp. $2 d$ at 487.

301. See Suzette M. Malveaux, Statutes of Limitations: A Policy Analysis in the Context of Reparations Litigation, 74 GEO. WASH. L. REV. 68, 89-90 (2005) (providing the general rule that a defendant cannot assert a time limitation if the defendant intentionally or unintentionally induced the plaintiff to postpone filing a complaint); Eli J. Richardson, Eliminating the Limitations of Limitations Law, 29 ARIZ. ST. L.J. 1015, 1043 (1997) (“Equitable estoppel prohibits a defendant from being able to involve the statute of limitations defense where he has taken active steps to prevent a plaintiff from timely filing."). 
record. ${ }^{302}$ The court stated: “These documents suggest that Flechtheim's liquidation was precipitated by his acute financial troubles, going back as far as 1931, before the Nazis came to power .... Notwithstanding his financial missteps, Flechtheim continued to consign Grosz's works on an ad hoc basis until his death in London in 1937."303 This judgment ignores systematic boycotting and extortion of Jews to gain their property, in and out of the Reich, starting in 1933 and with imposition of the Flight Tax, which actually should be considered matters appropriate for judicial notice. ${ }^{304}$ Moreover, the massive Nazi theft of art is well documented, not only as a general historical fact, but also as a specific fact about Flechtheim's galleries in Berlin and Dusseldorf in a 2001 report of the Independent Commission of Experts Switzerland (ICE), also known as the Bergier Commission. ${ }^{305}$ The report found the Flechtheim gallery was raided and boycotted by the Nazis and was Aryanized; the relevant excerpts are as follows:

As early as in March 1933 the Nazis raided an auction at the Duesseldorf branch [of the Flechtheim Galleries] which consequently had to be stopped.

A few days later an attack article appeared in the "Volksparole" ("People's Word") under the headline "Misguided Patronage: How Flechtheim and Kaesbach Made German Art." The boycott drove the company to the brink of ruin. The branches in Berlin and Duesseldorf were "aryanized" in November 1933; subsequently Flechtheim was expelled from the Reich Chamber of Culture.

Due to the boycott measures and the negative press in connection with the "aryanization" of Galerie Flechtheim, Alex Voemel [who took over the Flechtheim Galleries] was faced with a large amount of debt and attempted to satisfy creditors by "payment in kind," i.e. the pledging of works of art from the storage and private collection of Flechtheim.

Flechtheim's estate was later sold via a sham auction in the Netherlands, which MoMA alleged was a perfectly legal transaction. ${ }^{307}$

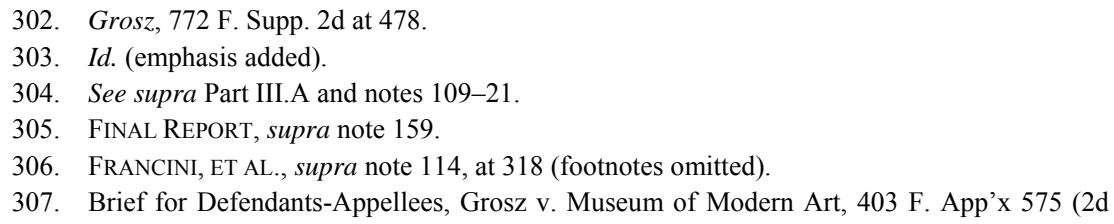


The works later passed through Curt Valentin. ${ }^{308}$ Again, Valentin was the partner of Karl Buchholz, one of Goebbels' four authorized dealers for art deemed degenerate by the Nazis. ${ }^{309}$ Buchholz was listed as a "red flag" name in the 1946 final report issued by the U.S. War Department's Art Looting Investigation Unit. ${ }^{310}$

MoMA's experts advanced theories that Flechtheim or his wife gifted Poet to Charlotte Weidler or that she received it as an inheritance. ${ }^{311}$ MoMA's experts opined, based on their review of documents - never even made available to the Grosz heirs in the course of litigation - that Weidler had an "anti-Nazi reputation." 12 In astonishing contrast to this characterization, the Grosz heirs' historian unearthed a letter from Weidler to the Carnegie Institute, dated October 30, 1939, after the Nazi invasion of Poland, which states: "They are nice in the Propoganda [sic] Ministr[y] and they told me again that they are much interested in the Carnegie-Institute and because your sales will bring dollars in the country." 313

The dismissal of Grosz cannot be squared with the standards announced in Twombly and Iqbal. To the contrary, the massive Nazi theft of art is well documented, including specific facts about Flechtheim's galleries in Berlin and Dusseldorf. ${ }^{314}$ There is also a powerful historical consensus about the Nazi program of selling stolen artwork to American collectors and museums. ${ }^{315}$ It is further widely acknowledged that the chief obstacle complicating provenance research is that the Nazis went out of their way to disguise their grand larceny as a

Cir. 2010) (No. 10-257), 2010 WL 3948664, at*7.

308. Curt Valentin Papers in The Museum of Modern Art Archives, MoMA, http:// moma.org/learn/resources/archives/EAD/Valentinf (last visited Aug. 31, 2012); see also supra notes 164-68 and accompanying text.

309. See supra notes $165-68$ and accompanying text.

310. Post-War Reports: Art Looting Intelligence Unit (ALIU) Reports 1945-1946 and ALIU Red Flag Names List and Index, LOOTEDART.COM, http://www.lootedart.cm/aliv-long (last visited Sept. 17, 2012). See generally Nancy H. Yeide, The Plunder of Art as a War Crime: The Art Looting Investigation Unit Reports and the Hermann Goering Art Collection, 8 RUTGERS J.L. \& RELIGION 13 (2007) (discussing the systematic and selfish confiscation of artwork by Reichsmarshall Herman Goering).

311. Corrected and Amended Expert Report of Laurie A. Stein, Grosz v. Museum of Modern Art, 772 F. Supp. 2 d 473 (S.D.N.Y. 2010) (09 Civ. 3706), 2009 WL 6485929.

312. Id.

313. Letter from Charlotte Weidler to Homer Saint-Gaudens at Carnegie Institute, Dep't of Fine Arts (Oct. 30, 1939) (on file with the Kansas Law Review).

314. FINAL REPORT, supra note 159.

315. See supra Part III. 
series of open transactions between willing sellers and buyers. ${ }^{316}$ Under New York law, the burden of demonstrating title lies with the presentday possessor. ${ }^{317}$ In light of such uniform scholarly consensus and the burden of proof, the district court should have held that the complaint satisfied the Twombly-Iqbal standard of plausibility.

Moreover, it is good fundamental policy to encourage communication for negotiation and settlement purposes. ${ }^{318}$ Precisely to secure meaningful negotiations, courts should toll the state statute of limitations for the duration of negotiation and settlement discussions. ${ }^{319}$ In addition to complying with fundamental policy applicable to all litigation, such a course also furthers the Washington Principles and Terezín Declaration. ${ }^{320}$ Precedent to the contrary is lamentable. The country that led the way in organizing worldwide support for the Washington Principles now has a great deal of federal judicial precedent that distorts historical remembrance and even encourages - in fact dictates - that parties run to the courthouse instead of negotiate in good faith over the restitution of Holocaust-era assets that were unlawfully seized during the height of genocidal cruelty. Lowry's language indicating that MoMA wanted to continue to pursue a just and fair solution set up an agreement to continue research for years and share ownership forever in no way notified Jentsch or the Grosz heirs that MoMA had refused to continue working toward an agreement. This kind of cooperation in search of a just and fair solution instead of litigation is exactly what the Washington Principles, Terezín Declaration, and AAMD Guidelines encourage.

The court was prone to make these legal errors because it also wrongly denied discovery of documents relevant to MoMA's chain of

316. See Amy Newman, The Nuremberg Laws: Institutionalized Anti-Semitism 79 (1999) ("[T]he effort to return stolen art to its original owners has been hampered by falsified sales documents ...").

317. Bakalar v. Vavra, 619 F.3d 136, 141-42 (2d Cir. 2010) (citing Solomon R. Guggenheim Found. v. Lubell, 569 N.E.2d 426 (N.Y. 1991)).

318. E.g., Rein v. Socialist People's Libyan Arab Jamahiriya, 568 F.3d 345, 352 (2d Cir. 2009).

319. Yasuhei Taniguchi, Good Faith and Abuse of Procedural Rights in Japanese Civil Procedure, 8 TUL. J. INT'L \& COMP. L. 167, 180 (2000) (“[T] he parties to a litigation seem to have a legitimate interest in keeping an action alive while negotiating a settlement. The statute of limitation is tolled while an action is pending."). See generally Stephanie Cuba, Note, Stop the Clock: The Case to Suspend the Statute of Limitations on Claims for Nazi-Looted Art, 17 CARDOZO ARTS \& ENT. L.J. 447 (1999) (discussing the need to suspend the statute of limitations regarding stolen artwork because many people are now locating missing art or realizing they have a potential claim).

320. See supra notes $36-41$ and accompanying text. 
title for the paintings. ${ }^{321}$ The Grosz heirs' appellate brief lays out the issue nicely:

From May 2009 through December 2009 document discovery and depositions, including art history expert and foreign legal expert discovery, was completed with the exception of outstanding disputes over inter alia MoMA's refusal to permit inspection of provenance documentation of Nazi-era artworks in its collections from Flechtheim's inventory and from Charlotte Weidler and Curt Valentin, the art dealers who sold Poet to MoMA.

As reflected in MoMA's proposed expert reports, MoMA's theory of the case is that the post-March 1933 sales of Flechtheim's inventory were legal, that the Dutch sales of Flechtheims' estate was legal and that Weidler received Poet as an inheritance from Flechtheim's estate or as a gift from Flechtheim's wife Betty after his death.

During discovery, the Grosz Heirs tried to explore MoMa's documents related to Flechtheim's inventory and into artworks acquired through Weidler and Valentin and were blocked. In stark contrast, MoMA's purported expert art historians had free reign of MoMA's documents during discovery.

$\cdots$

... It is standard, and indeed required, practice in provenance research to research all items in a lost art collection to understand the circumstances of its dispersal. MoMA's website shows five artworks that were in Alfred Flechtheim's inventory in 1933. Yet the Grosz Heirs were denied discovery into MoMA's documentation of the provenance of these artworks. ${ }^{322}$

Finally, the court was completely uninformed as to how the allegations should be viewed, and shut down discovery into the full factual context, which was necessary to correctly understand the allegations. The Grosz heirs' appellate brief has it absolutely correct: "[T]he District Court should have permitted discovery into artworks in MoMA's collection that came from Flechtheim, Weidler and Valentin to permit the Grosz heirs to ... [rebut] MoMA's defense that Flechtheim's liquidation was legitimate ....",323 Furthermore, the judge's manner of

321. Brief and Special Appendix for Plaintiffs-Appellants, supra note 285, at 24.

322. Id. at $* 20$ (citations omitted).

323. Id. at $* 53$. 
dealing with the discovery dispute seems oddly emotional, such as where she noted that additional letters to the court by the parties would be placed in the trash. ${ }^{324}$ She also criticized some of the Grosz heirs' evidence as "rank hearsay" 325 even though there is absolutely no requirement in any rule that a complaint must rely solely on admissible evidence. ${ }^{326}$

In conclusion, it was improper to dismiss the case by divorcing it from historical context and forbidding inquiry into the proper context via discovery. As Katzenbach noted, "[a]fter many years crucial documents are missing and the thousands of pages of records and correspondence reviewed often do not provide clear answers." ${ }^{\text {227 }}$ As Judge McMahon of the district court noted: "[m]atters of provenance are notoriously complicated, and the circumstances under which the Paintings made their way to MoMA (as alleged by Plaintiffs) made the museum's investigation difficult." 328 Ownership decisions, even those made on technical grounds like the statute of limitations, turn on context-sensitive facts that require historical analysis to understand. These issues are not appropriately decided on a motion to dismiss, filed early in the case. Courts should allow the full light of history to illuminate the record to determine whether a Holocaust-era art complaint is plausible and should survive a motion to dismiss. More specifically, because provenance evidence is highly relevant to the resolution of disputes over rightful ownership, courts should not treat such evidence as confidential or privileged, or-as the district court did in this case-"rank hearsay" unworthy of supporting an allegation in a complaint filed before the discovery process even begins. Doing so is not only improper as a matter of procedure, but it endorses a false view of historical reality and distorts the historical record.

\section{Obstacles to Claims that Survive a Motion to Dismiss}

Even surmounting a motion to dismiss or motion for summary judgment does not guarantee a survivor or heir success. Bakalar $v$. Vavra is a dispute between the heirs of Fritz Grunbaum and David

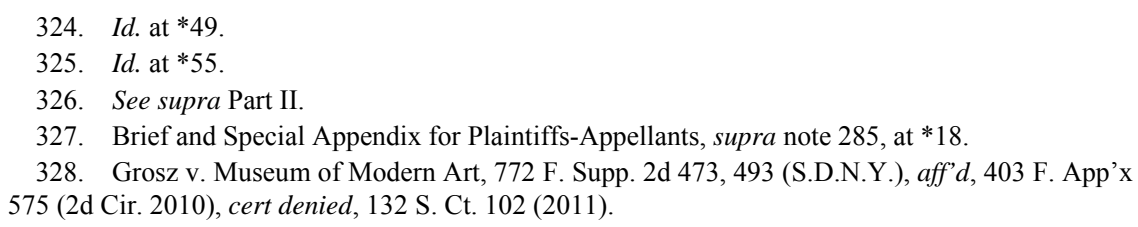


Bakalar, who filed an action for declaratory judgment, tortious interference with contractual relations, and slander of title with regard to Seated Woman with Bent Left Leg (Torso), a drawing by Egon Schiele. ${ }^{329}$ Fritz Grunbaum, prominent Jewish entertainer in Vienna with a significant art collection, was arrested eight days after the March 12, 1938, Anschluss. ${ }^{330}$ He was shipped to the Dachau concentration camp where he was forced to sign a power of attorney certificate before he died, on January 14, 1941, to provide his wife, Elisabeth, with the legal power to claim his assets and file property declarations in accordance with Nazi law. ${ }^{331}$

In a report dated four days after the execution of the power of attorney, Franz Kieslinger, an appraiser for the Nazis with the Viennese auction house Dorotheum - which was 'a prime selling point of loot[ed] art in Austria'...[-] conducted an appraisal of the 449 artworks that Grunbaum kept in his apartment ....

Before being arrested and shipped off to her death in the Minsk concentration camp in October 1942, Elisabeth was forced to sign an inventory in accordance with the power of attorney, which adopted Kieslinger's exact valuation on the art collection. ${ }^{333}$ Later she signed Fritz's death certificate, which stated that "there is no estate ... [and] in the absence of an estate, there are no estate-related proceedings.",334

Eberhard Kornfeld, a partner in the Swiss art gallery Gutekunst \& Klipstein founded by Otto Kallir, acquired Fritz's artworks. ${ }^{335}$ The gallery is known to have sold artworks seized by the Nazis. ${ }^{336}$ It sold the Schiele drawing, approximately six months after purchasing it in 1956, to a New York gallery, which subsequently sold it to David Bakalar in $1963 .{ }^{337}$

329. No. 05 Civ. 3037 (WHP) 2008 WL 4067335, at*1 (S.D.N.Y. Sept. 28, 2008), vacated, 619 F.3d 136 (2d Cir. 2010), remanded to 819 F. Supp. 2d 293 (S.D.N.Y. 2011), aff'd, No. 11-4042-cv, 2012 WL 4820801 (2d Cir. Oct. 11, 2012). The tortious interference and slander of title claims have since been dropped.

330. Id. at *3.

331. Id.; Bakalar v. Vavra, 619 F.3d 136, 148 (2d Cir. 2010) (Korman, J., concurring) (discussing how Grunbaum was forced to execute the power of attorney).

332. Bakalar, 619 F.3d at 138 (majority opinion).

333. Id.

334. Bakalar, $2008 \mathrm{WL} 4067335$, at *4.

335. See supra Part IV.C.

336. Vivian Endicott Barnett, Rereading the Correspondence: Rebay and Kandinsky, in ART OF TOMORROW: Hilla REBAY AND SOLOMON R. GUGGENHEIM 86, 99 (2005).

337. Bakalar, $2008 \mathrm{WL} 4067335$, at *1. Interestingly, in an earlier attempt to certify a defendant 
After a trial on the merits, the court found that Bakalar's title traced back to a sale by Fritz Grunbaum's sister-in-law Mathilde Lukacs, whom the court found received the painting as a gift from Elisabeth and subsequently sold it to Kornfeld. ${ }^{338}$ Although adopted as fact by the trial court, Kornfeld's testimony and the evidence of the 1956 sale have been questioned by Jonathan Petropolous, a prominent historian who has thoroughly researched Nazi-era trafficking and who was hired by the Grunbaum heirs. ${ }^{339}$ Under the trial court's theory, the power of attorney signed by Fritz Grunbaum in Dachau must have given Elisabeth the power to make a valid gift of the painting to his sister-in-law in Nazi Vienna-after Fritz died intestate and shortly before Elisabeth was shipped off to her death.

The Second Circuit vacated and remanded the case. ${ }^{340}$ The Second Circuit found that the district court erred under New York law in its choice of law analysis-New York law should have controlled, not Swiss law ${ }^{341}$ - and by placing the burden of proof as to title on the claimant. $^{342}$ The court noted that New York case law places the onerous "burden of investigating the provenance of a work of art on the potential purchaser," 343 to prevent New York, the largest art market in the world, from fostering trafficking of stolen art. ${ }^{344}$ The Second Circuit found that the trial court erred in concluding that the "Grunbaum heirs had failed to produce 'any concrete evidence that the Nazis looted the Drawing or that it was otherwise taken from Grunbaum." "345 The court continued: "Our

class of present-day possessors of Fritz Grunbaum's art, the Grunbaum heirs sought discovery from Galerie St. Etienne, Sotheby's, and Christie's to identify owners or possessors of artworks previously belonging to Fritz Grunbaum and provenance documents for those artworks, an attempt that the trial court disallowed. Bakalar v. Vavra, 237 F.R.D. 59, 65 (S.D.N.Y. 2006).

338. Bakalar, 2008 WL 4067335, at *2.

339. See Supplemental Expert Opinion, Bakalar v. Vavra, 2008 WL 4067335 (S.D.N.Y. Sept. 2, 2008) (No. 05 Civ. 3037(WHP)) (admitted into the Record by the Second Circuit in March 2009) (on file with author).

340. Bakalar v. Vavra, 619 F.3d 136, 146 (2d Cir. 2010), remanded to 819 F. Supp. 2d 293 (S.D.N.Y. 2011), aff'd, No. 11-4042-cv, 2012 WL 4820801 (2d Cir. Oct. 11, 2012).

341. Id.

342. Id. at 147.

343. Id. at 143 (quoting Solomon R. Guggenheim Found. v. Lubell, 569 N.E. 2d 426, 431(N.Y. 1991)). The court also noted that New York's governor vetoed a bill to change New York law on this point. Id. at 142 .

344. Id.; see also id. at 144 (noting that this New York policy serves "as a means to preserve the integrity of transactions and prevent the state from becoming a marketplace for stolen goods" (quoting Kunstsammlungen Zu Weimar v. Elicofon, 536 F. Supp. 829 (E.D.N.Y. 1981)).

345. Id. at 147 (quoting Bakalar v. Vavra, No. 05 Civ. 3037 (WHP), 2008 WL 4067335, at *8 (S.D.N.Y. Sept. 2, 2008)). 
reading of the record suggests that there may be such evidence, and that the district judge, by applying Swiss Law, erred in placing the burden of proof on the Grubaum heirs in this regard." 346 The court did not provide detailed analysis of the factual record.

The court went on to endorse the lower court's denial of discovery related to the potential certification of a defendant class of possessors of artworks from the Grunbaum collection, finding that Judge Pauley of the district court did not engage in any abuse of discretion. ${ }^{347}$ The court also noted that "should the district judge conclude that the Grunbaum heirs are entitled to prevail on the issue of the validity of Bakalar's title to the Drawing, the district judge should also address the issue of laches." 348

Judge Korman wrote a separate concurrence to address the perceived errors in the trial court's ruling, finding that the risks of writing dicta were outweighed by the need to direct the lower court judge to correctly interpret the factual evidence of Nazi looting. ${ }^{349}$ Judge Korman provided the following summary:

Grunbaum was arrested while attempting to flee from the Nazis. After his arrest, he never again had physical possession of any of his artwork, including the Drawing. The power of attorney, which he was forced to execute while in the Dachau concentration camp, divested him of his legal control over the Drawing. Such an involuntary divestiture of possession and legal control rendered any subsequent transfer void.

Judge Korman's critique of the district court's findings of fact, supporting the present-day possessor's argument "that someone in the Grunbaum family more likely than not exported the Drawing from Vienna, is highly compelling." 351 Judge Korman further clarified:

\footnotetext{
346. Id. at 147 .

347. Id.

348. Id. at 147. On remand, the court dismissed the case on laches grounds. Bakalar v. Vavra, 819 F. Supp. 2d 293 (S.D.N.Y. 2011). The Second Circuit affirmed. Bakalar v. Vavra, No. 114042-cv, 2012 WL 4820801, at*3 (2d Cir. Oct. 11, 2012).

349. Id. at 148 (Korman, J., concurring).

350. Id. Judge Korman distinguished this scenario from a bailment scenario where title could potentially pass to a subsequent good faith purchaser for value. Id. Judge Korman correctly pointed out that the lower court erred in applying U.C.C. § 2-403(1), which could only apply in voidable title bailment scenarios. Id. at 149. Because the power of attorney signed by Grunbaum was involuntary, "any subsequent transfer was void and not merely voidable." Id. Judge Korman found an analogy in Vineberg v. Bissonnette, 548 F.3d 50 (1st Cir. 2008), aff'g 529 F. Supp. 2d 300, 307 (D.R.I. 2007), the only Nazi-looted art case in U.S. courts since 2004 in which a claimant was successful. Bakalar, 619 F.3d at 149 (Korman, J., concurring).

351. Bakalar, 619 F.3d at 151 (Korman, J., concurring).
} 
The district judge merely speculated that "[t]he Drawing could have been one of the 417 drawings Elisabeth Grunbaum possibly exported ... in 1938," or that the Drawing "could have been one of three drawings Lukacs's husband exported," or that "it could have been" one of the three watercolors exported by Lukacs's brother-inlaw. These scenarios, based on pure speculation, do not constitute findings by a preponderance of the evidence that what "could have" happened actually did happen.

Judge Korman also challenged Bakalar's claim on appeal that there is no "direct evidence that all of the Schiele art sold by Lukacs had once belonged to Fritz Grunbaum," or that "the Drawing belonged to Fritz Grunbaum prior to or during the war." ${ }^{, 35}$ Judge Korman stated that "there is significant circumstantial evidence that this artwork had belonged to him." 354 Judge Korman pointed out that the underlying theories of the case had assumed as much, including deposition testimony of Kornfeld and the trial testimony of Jane Kallir, Otto Kallir's daughter, and the current director of Galerie St. Etienne. ${ }^{355}$ The 2005 Sotheby's auction record that triggered the entire litigation stated as much as well. ${ }^{356}$ Bakalar's initial complaint even admitted the same. ${ }^{357}$ Unfortunately, on remand, the district court again found against Vavra and dismissed the case; the Second Circuit affirmed; a petition for rehearing en banc was filed. ${ }^{358}$

\section{CONClusion: COURTS Should HeEd History AND Welcome HISTORIANS}

Even once courts understand the plausibility of the allegation that an artwork was stolen or subject to a forced sale during the Nazi era, it is likely that courts will still need assistance to evaluate the particular facts surrounding the asserted legal claims and defenses. There is a risk that lawyers and judges lacking expertise in historical research who rely on

352. Id. (citation omitted) (quoting Bakalar v. Vavra, No. 05 Civ. 3037 (WHP), 2008 WL 4067335 , at *8 (S.D.N.Y. Sept. 2, 2008)).

353. Id.

354. Id

355. Id.

356. Id.

357. Id

358. Bakalar v. Vavra, No. 11-4042-cv, 2012 WL 4820801 (2d Cir. Oct. 11, 2012); Petition for Rehearing with Suggestion for Rehearing En Banc, Bakalar, 2012 WL 4820801 (2d Cir. Oct. 11, 2012) (No. 11-4042-cv) (on file with author). 
"law-office history," will misinterpret facts. ${ }^{359}$ On the other hand, in one scholar's view,

[Judges] need advocates, and in some instances historians, to present the history. The likelihood that the courts will produce credible decisions rooted in history increases dramatically when the effort is a partnership between the bench and bar, as opposed to an effort by one judge and one star-crossed law clerk.

Historians are increasingly being asked to offer their testimony in American courts as expert witnesses. ${ }^{361}$ Historians have participated in cases adjudicating a wide variety of claims, such as "gay rights, gender discrimination, voting rights, tobacco litigation, naturalization proceedings against defendants suspected of failing to disclose ties to organizations hostile to the United States, and Native-American hunting and fishing rights." 362 The use of historians' testimony, like the testimony of all expert witnesses, is subject to the requirements of Rule 702 of the Federal Rules of Evidence. ${ }^{363}$ Even assuming the evidentiary hurdle is overcome, historical explanations are subtle and complex interpretations of human experience; therefore, the historical method is at odds with the needs of the court, which ultimately requires categorical, definitive conclusions. ${ }^{364}$

Although historians have been very useful in Nazi-looted art litigation, there is some risk to the historical record when an historian is forced, in our adversarial system, to reduce her research into sound bites or cloak advocacy as objective scholarship. ${ }^{365}$ This Article does not address proposed reforms to combat this problem, inherent in the use of any expert in our adversarial courts, ${ }^{366}$ but simply posits that judges

359. Jeffrey S. Sutton, Essay, The Role of History in Judging Disputes About the Meaning of the Constitution, 41 TEX. TECH. L. REV. 1173, 1185 (2009).

360. Id. at 1188.

361. Jonathan D. Martin, Historians at the Gate: Accommodating Expert Historical Testimony in Federal Courts, 78 N.Y.U. L. REV. 1518, 1519 (2003).

362. Maxine D. Goodman, Slipping Through The Gate: Trusting Daubert and Trial Procedures to Reveal the 'Pseudo-Historian' Expert Witness and to Enable the Reliable Historian Expert Witness-Troubling Lessons from Holocaust-Related Trials, 60 BAYLOR L. REV. 824, 831 (2008) (footnotes omitted).

363. Martin, supra note 361, at 1520.

364. Id. at 1534-36.

365. See Goodman, supra note 362 , at 826 (defining a "pseudo-historian" as someone presented to the court as an expert but who relays propaganda instead of fact-based history).

366. Many proposed reforms, such as those calling for panels of experts and sole reliance upon court-appointed experts would have practicality problems in the historical analysis of Holocaust-era 
contemplating questions whether a particular artwork was looted, the ability of owners to reclaim their property, and the ability of purchasers to claim good faith purchaser status under foreign law should be informed by history-and reliance on historians may assist in developing the requisite knowledge to accurately assess the plausibility of the parties' claims and defenses. ${ }^{367}$

At the same time, courts listening to expert historians must be openminded because historical analysis, like much other science, is imperfect and research is highly subjective and built on a series of assumptions and inferences used to ferret out errors and inconsistencies. ${ }^{368}$ On the other hand, judges contemplating inconsistent interpretations of events proffered by opposing expert historians should not allow junk history to infect the historical record contained within judicial decisions. ${ }^{369}$ Applying ordinary evidentiary safeguards should help combat this problem, ${ }^{370}$ as should certain safeguards appropriate when considering

expropriation and forced sales because of the small number of historians that are truly experts in the field. See Jan Beyea \& Daniel Berger, Scientific Misconceptions Among Daubert Gatekeepers: The Need for Reform of Expert Review Procedures, 64 LAW \& CONTEMP. ProBs. 327, 365 (2001) (calling for courts to form teams or panels of scientific reviewers akin to the academic peer review publication process); Anthony Champagne, et al., Are Court-Appointed Experts the Solution to the Problems of Expert Testimony?, 84 JUdiCATURE 178, 183 (2001) (calling for court-appointment of experts); Michael Connolly \& John Muir, Special Masters, Court-Appointed Experts and Technical Advisors in Federal Court, 76 DEF. Couns. J. 77, 77 (2009) (calling for court appointment); Sophia Cope, Ripe for Revision: A Critique of Federal Rule of Evidence 706 and the Use of CourtAppointed Experts, 39 GonZ. L. REV. 163, 170-77 (2004) (offering critique of oft-advocated reform). But see Robert L. Hess, II, Judges Cooperating with Scientists: A Proposal for More Effective Limits on the Federal Trial Judge's Inherent Power to Appoint Technical Advisors, 54 VAND. L. REV. 547, 549 (2001) (arguing that court appointments inappropriately give judicial power to third parties, and parties' power to judges); N.E.H. Hull \& Peter Charles Hoffer, Historians and the Impeachment Imbroglio: In Search of a Serviceable History, 31 RUTGERS L.J. 473, 489-90 (2000) (calling for Congress to appoint historians to special committees attending to issues of great public importance where understanding historical context is key).

367. See generally Reuel E. Schiller, The Strawhorsemen of the Apocolypse: Relativism and the Historian as Expert Witness, 49 HASTINGS L.J. 1169, 1176 (1998) (exposing the theory that historians are under so much attack outside of court that their credibility already comes under intense scrutiny in court).

368. Beyea \& Berger, supra note 366 , at 332.

369. Cf. Jeffrey Lynch Harrison, Reconceptualizing the Expert Witness: Social Costs, Current Controls, and Proposed Responses, 18 YALE J. ON REG. 253 (2001) (noting that the adversarial system allows for "hired-gun" experts and generates significant social cost).

370. See generally Miles J. Vigilante, Screening Expert Testimony After Kumho Tire Co. v. Carmichael, 8 J.L. \& POL'Y 543 (2000) (discussing evidentiary standards regularly applicable to experts); Stephen D. Easton, That Is Not All There Is: Enhancing Daubert Exclusion By Applying “Ordinary” Witness Principles to Experts, 84 NeB. L. REV. 675 (2006) (advocating for use of heightened safeguards such as would be applied to nonexpert witnesses). 
testimony from social scientists. ${ }^{371}$ When considering testimony from an historian, courts should pay heed to whether the purported scholar treated sources with skeptical reservation; did not automatically disregard contrary evidence; was balanced in her treatment of the evidence and did not cherry-pick; highlighted speculations; did not omit any part of a relevant document; weighed the authenticity of everything, not just the accounts in contradictions; and considered the motives of all historical actors. ${ }^{372}$

Almost every Nazi-looted art claim since 2004 has been dismissed on technical grounds, most commonly the statute of limitations. ${ }^{373}$ But how are these courts determining whether the claimants should be given a chance to be heard? The courts usually rely on evidence such as sales records of the art submitted by the museums and Nazi-looted art possessors. But what if the evidence is falsified, no matter how legal it appears?

From the confiscation process within the Reich evolved a complex system of mutual consultation between officials, which also incorporated private institutions such as banks and insurance companies within the network. ${ }^{374}$ The system, developed for the phase of emigration, was thereby adapted for the confiscation of the property of German Jew deportees. ${ }^{375}$ Its goal was to achieve complete exploitation of Jewish property by enforcing "legal" confiscation under the Eleventh Decree, itself an extension of previous denaturalization and confiscation policies. ${ }^{376}$ The very scale of the measures taken to seize and distribute Jewish property demonstrates both widespread knowledge of the deportations and the crucial legal aspect of the Final Solution. ${ }^{377}$

371. See Wendie Ellen Schneider, Note, Past Imperfect, 110 YALE L.J. 1531 (2001) (arguing for the application of a "conscientious historian" standard in American cases employing historians as expert witnesses).

372. See id. at 1540 (describing how the conscientious historian standard would work in practice). Cf. Saul Cornell, Heller, New Originalism, and Law Office History: "Meet the New Boss, Same as the Old Boss," 56 UCLA L. REv. 1095 (2009) (critiquing Justice Scalia's having engaged in faulty historical analysis to announce "new originalism"); Saul Cornell, Originalism on Trial: The Use and Abuse of History in The District of Columbia v. Heller, 69 OHIO ST. L.J. 625 (2008) (accusing Justice Scalia of having failed to employ standards of acceptable historical scholarship in utilizing "atypical texts" and dismissing or ignoring influential countervailing historical scholarship).

373. See supra Part II; see also Brief for Am. Jewish Congress as Amici Curiae, supra note 286, at a-7 app.B, available at http://papers.ssrn.com/sol3/papers.cfm?abstract_id=1628670.

374. See DEAN, supra note 109, at 245.

375. Id. at 110 .

376. Id.

377. Id. at 256 
We cannot expect judges to understand all aspects of the complicated history behind Nazi-looted art. Even expert historians in the field require a significant amount of time to complete any successful provenance research. However, judges in this country need to understand why they should welcome historians as expert witnesses in Nazi-looted art cases, how the history should never be overlooked in these cases, and how the historians sometimes are the only ones able to accurately analyze documentation from the relevant period. What at first does not seem to comport with common sense, may do so, once one is fully informed.

VI. APPENDIX: Federal Holocaust-ERA ART Claims SinCE 2004, UPDATED BY JENNIFER ANGLIM KREDER OCTOBER 26, 2012

\section{Cases Lost by Holocaust Victims or Their Heirs}

\begin{tabular}{|c|c|c|c|c|}
\hline & Case Name & Case Number & $\begin{array}{l}\text { Citation or Court in } \\
\text { Which Pending }\end{array}$ & Disposition \\
\hline 1 & $\begin{array}{l}\text { Bakalar v. } \\
\text { Vavra }\end{array}$ & $11-4042-\mathrm{cv}$ & $\begin{array}{l}2012 \text { WL } 4820801 \\
\text { (2d Cir. Oct. 11, } \\
\text { 2012). }\end{array}$ & $\begin{array}{l}\text { Claimant lost after trial, } \\
\text { incorrect choice-of-law, } \\
\text { burden of proof analysis } \\
\text { and interpretations of fact } \\
\text { indicative of Nazi looting. } \\
\text { Second Circuit reversed. } \\
\text { On remand, claimant lost } \\
\text { again. Second Circuit } \\
\text { affirmed. }\end{array}$ \\
\hline 2 & $\begin{array}{l}\text { Von Saher v. } \\
\text { Norton Simon } \\
\text { Museum of } \\
\text { Art at } \\
\text { Pasadena }\end{array}$ & $07-56691$ & $\begin{array}{l}\text { 592 F.3d 954 (9th } \\
\text { Cir. Jan. 14, 2010). }\end{array}$ & $\begin{array}{l}\text { Court struck down all } \\
\text { claims filed pursuant to } \\
\text { California statute } \\
\text { extending limitations } \\
\text { period to } 2010 \text { and } \\
\text { remanded to determine } \\
\text { whether statute of } \\
\text { limitations has run on } \\
\text { common law conversion } \\
\text { claim. Solicitor General } \\
\text { recommended SCOTUS } \\
\text { deny certiorari, which } \\
\text { SCOTUS did. Defendants } \\
\text { on remand filed a motion } \\
\text { to dismiss, which was } \\
\text { granted by the court. }\end{array}$ \\
\hline 3 & $\begin{array}{l}\text { Westfield v. } \\
\text { Fed. Republic } \\
\text { of Germany }\end{array}$ & $09-6010$ & $\begin{array}{l}633 \text { F.3d } 409 \text { (6th } \\
\text { Cir. 2011). }\end{array}$ & $\begin{array}{l}\text { Court ruled that Germany } \\
\text { could not be sued under } \\
\text { Foreign Sovereign } \\
\text { Immunities Act (FSIA) for } \\
\text { any taking of property } \\
\text { during the war on the } \\
\text { ground that the taking had } \\
\text { no "direct effect" in the } \\
\text { U.S. Sixth Circuit } \\
\text { affirmed. }\end{array}$ \\
\hline
\end{tabular}




\begin{tabular}{|c|c|c|c|c|}
\hline 4 & $\begin{array}{l}\text { Grosz v. } \\
\text { Museum of } \\
\text { Modern Art }\end{array}$ & $\begin{array}{l}09-C V-3706 \\
(\mathrm{CM})\end{array}$ & $\begin{array}{l}403 \text { F. App'х. } 575 \\
\text { (2d Cir. 2010), cert. } \\
\text { denied, 132 S. Ct. } \\
102 \text { (2011). }\end{array}$ & $\begin{array}{l}\text { Court granted museum's } \\
\text { motion to dismiss the on } \\
\text { ground that recently } \\
\text { exchanged letters triggered } \\
\text { demand and refusal such } \\
\text { that the statute of } \\
\text { limitations just barely ran } \\
\text { out. Affirmed on appeal. } \\
\text { SCOTUS denied petition } \\
\text { for certiorari. }\end{array}$ \\
\hline 5 & $\begin{array}{l}\text { Museum of } \\
\text { Fine Arts, } \\
\text { Bos. v. Seger- } \\
\text { Thomschitz }\end{array}$ & $09-1922$ & $\begin{array}{l}623 \text { F.3d } 1 \text { (1st Cir. } \\
2010) \text {, cert. denied, } \\
131 \text { S. Ct. } 1612 \\
\text { (2011), reh'g } \\
\text { denied, } 131 \mathrm{~S} . \mathrm{Ct} . \\
2176 \text { (2011). }\end{array}$ & $\begin{array}{l}\text { Court granted museum's } \\
\text { motion for summary } \\
\text { judgment declaring its } \\
\text { superior interest in } \\
\text { painting. Affirmed on } \\
\text { appeal. SCOTUS denied } \\
\text { petition for certiorari and } \\
\text { petition for rehearing. }\end{array}$ \\
\hline 6 & $\begin{array}{l}\text { Dunbar v. } \\
\text { Seger- } \\
\text { Thomschitz }\end{array}$ & 09-30717 & $\begin{array}{l}615 \text { F.3d } 574 \text { (5th } \\
\text { Cir. 2010), cert. } \\
\text { denied, 131 S. Ct. } \\
1511(2011) .\end{array}$ & $\begin{array}{l}\text { Prescriptive ownership by } \\
\text { present-day possessor } \\
\text { under Louisiana law; } \\
\text { motion for summary } \\
\text { judgment granted. } \\
\text { Affirmed on appeal. } \\
\text { SCOTUS denied petition } \\
\text { for certiorari. }\end{array}$ \\
\hline 7 & $\begin{array}{l}\text { Orkin v. } \\
\text { Taylor }\end{array}$ & $05-55364$ & $\begin{array}{l}487 \text { F.3d } 734 \text { (9th } \\
\text { Cir. 2007), cert. } \\
\text { denied, 552 U.S. } \\
990 \text { (2007). }\end{array}$ & $\begin{array}{l}\text { Holocaust Victims Redress } \\
\text { Act did not create a private } \\
\text { right of action. State law } \\
\text { claims barred by statute of } \\
\text { limitations. Affirmed on } \\
\text { appeal. SCOTUS denied } \\
\text { certiorari. }\end{array}$ \\
\hline 8 & $\begin{array}{l}\text { Detroit Inst. } \\
\text { of Arts v. } \\
\text { Ullin }\end{array}$ & 06-10333 & $\begin{array}{l}2007 \text { WL } 1016996 \\
\text { (E.D. Mich. Mar. } \\
\text { 31, 2007). }\end{array}$ & $\begin{array}{l}\text { Declaratory judgment } \\
\text { issued to museum and } \\
\text { claimants' state law claims } \\
\text { dismissed on statute of } \\
\text { limitations grounds (claim } \\
\text { accrued in } 1938 \text { and } \\
\text { expired in } 1941 \text {, before the } \\
\text { end of WWII). }\end{array}$ \\
\hline 9 & $\begin{array}{l}\text { Toledo } \\
\text { Museum of } \\
\text { Art v. Ullin }\end{array}$ & 3:06 CV 7031 & $\begin{array}{l}477 \text { F. Supp. 2d } 802 \\
\text { (N.D. Ohio 2006) }\end{array}$ & $\begin{array}{l}\text { Declaratory judgment } \\
\text { issued to museum and } \\
\text { claimants' state law claims } \\
\text { dismissed on statute of } \\
\text { limitations grounds. } \\
\text { Analysis similar, but not } \\
\text { identical to Detroit Inst. of } \\
\text { Arts v. Ullin. }\end{array}$ \\
\hline 10 & $\begin{array}{l}\text { Orkin v. } \\
\text { Swiss } \\
\text { Confederation }\end{array}$ & 11-1414-cv & $\begin{array}{l}444 \text { F. App’x } 469 \\
\text { (2d Cir. 2011). }\end{array}$ & $\begin{array}{l}\text { Court granted motion to } \\
\text { dismiss for lack of } \\
\text { jurisdiction under FSIA } \\
\text { and Alien Tort Statute. } \\
\text { Affirmed on appeal. }\end{array}$ \\
\hline 11 & $\begin{array}{l}\text { In re } \\
\text { Flamenbaum }\end{array}$ & $\begin{array}{l}2012 \text { N.Y. Slip } \\
\text { Op. } 04165\end{array}$ & $\begin{array}{l}95 \text { A.D. 3d } 1318 \\
\text { (N.Y. App. Div. } \\
\text { May 30, 2012). }\end{array}$ & $\begin{array}{l}\text { Vorderasiatisches Museum } \\
\text { action for declaratory } \\
\text { judgment and replevin of a } \\
\text { gold tablet dated back to }\end{array}$ \\
\hline
\end{tabular}




\begin{tabular}{|l|l|l|l|}
\hline & & & $\begin{array}{l}\text { the 13th century BC in } \\
\text { possession of the } \\
\text { Flamenbaum estate. The } \\
\text { court found it was not } \\
\text { barred from laches theory } \\
\text { and reversed the lower } \\
\text { court's opinion, and found } \\
\text { that the museum had legal } \\
\text { title and a superior right to } \\
\end{array}$ \\
& & \begin{tabular}{l} 
the tablet. \\
\hline
\end{tabular} \\
\hline
\end{tabular}

Cases Won by Holocaust Victims or Their Heirs in Federal Court

\begin{tabular}{|c|l|l|l|l|}
\hline & Case Name & Case Number & $\begin{array}{l}\text { Citation or Court in } \\
\text { Which Pending }\end{array}$ & Disposition \\
\hline 1 & $\begin{array}{l}\text { Vineberg v. } \\
\text { Bissonnette }\end{array}$ & $08-1136$ & $\begin{array}{l}548 \text { F.3d 50 (1st } \\
\text { Cir. 2008). }\end{array}$ & $\begin{array}{l}\text { Affirmed District of Rhode } \\
\text { Island summary judgment } \\
\text { in favor or claimant. Only } \\
\text { case won by a claimant in } \\
\text { federal court since 2004. }\end{array}$ \\
\hline 2 & $\begin{array}{l}\text { In re "Cristo } \\
\text { Portacroce } \\
\text { Trascinato da } \\
\text { un Mangoldo" }\end{array}$ & $\begin{array}{l}4: 11-\mathrm{cv}-00571- \\
\text { RH-WCS }\end{array}$ & $\begin{array}{l}\text { (N.D. Fla. Nov. 4, } \\
\text { 2011). }\end{array}$ & $\begin{array}{l}\text { Civil forfeiture action filed } \\
\text { against Romanino painting } \\
\text { located at the Mary } \\
\text { Brogam Museum of Art in } \\
\text { Tallahassee, Florida. } \\
\text { Allegations are that the } \\
\text { painting was imported } \\
\text { contrary to law and } \\
\text { smuggled into the country } \\
\text { contrary to law. Italy } \\
\text { defaulted on seizure. }\end{array}$ \\
\hline
\end{tabular}

\section{Cases Settled After Complaint Filed in Federal Court}

\begin{tabular}{|c|l|l|l|l|}
\hline & Case Name & Case Number & $\begin{array}{l}\text { Citation or Court in } \\
\text { Which Pending }\end{array}$ & Disposition \\
\hline 1 & $\begin{array}{l}\text { Museum of } \\
\text { Modern Art v. } \\
\text { Schoeps }\end{array}$ & $\begin{array}{l}\text { 07 Civ. 11074 } \\
\text { (JSR) }\end{array}$ & $\begin{array}{l}\text { 549 F. Supp. 2d 543 } \\
\text { (S.D.N.Y. 2008). }\end{array}$ & $\begin{array}{l}\text { Case settled on the eve of } \\
\text { trial. }\end{array}$ \\
\hline 2 & $\begin{array}{l}\text { In re "Femme } \\
\text { en Blanc" }\end{array}$ & $\begin{array}{l}\text { CV 04- } \\
\text { 8333FMCAJW }\end{array}$ & $\begin{array}{l}\text { X62 F. Supp. 2d } \\
\text { X175 (C.D. Cal. } \\
\text { 2005). }\end{array}$ & $\begin{array}{l}\text { Case settled after present- } \\
\text { day possessor filed a } \\
\text { declaratory action against } \\
\text { the claimant. Claimant had } \\
\text { removed the painting from } \\
\text { California on the eve of a } \\
\text { hearing for a temporary } \\
\text { restraining order in the } \\
\text { state court case filed by the } \\
\text { claimant. The California } \\
\text { trial court judge then } \\
\text { dismissed the California } \\
\text { state case for lack of } \\
\text { subject matter jurisdiction. } \\
\text { The U.S. government then }\end{array}$ \\
\hline
\end{tabular}




\begin{tabular}{|c|c|c|c|c|}
\hline & & & & $\begin{array}{l}\text { filed this civil forfeiture } \\
\text { action seizing the painting. } \\
\text { The case then settled. }\end{array}$ \\
\hline 3 & $\begin{array}{l}\text { Republic of } \\
\text { Austria v. } \\
\text { Altmann }\end{array}$ & 03-13 & $\begin{array}{l}541 \text { U.S. } 677 \\
\text { (2004). }\end{array}$ & $\begin{array}{l}\text { FSIA allows jurisdiction } \\
\text { over foreign sovereign } \\
\text { regardless of whether the } \\
\text { conduct at issue predates } \\
\text { FSIA. Claimant won after } \\
\text { consenting to arbitration in } \\
\text { Vienna. }\end{array}$ \\
\hline 4 & $\begin{array}{l}\text { In re "Portrait } \\
\text { of Wally" }\end{array}$ & $\begin{array}{l}99 \text { Cv. } 9940 \\
\text { (LAP) }\end{array}$ & $\begin{array}{l}\text { 663 F. Supp. 2d } 232 \\
\text { (S.D.N.Y. 2009). }\end{array}$ & $\begin{array}{l}\text { Civil forfeiture action filed } \\
\text { in } 1999 \text { after grand jury } \\
\text { subpoena to seize painting } \\
\text { was quashed in state court } \\
\text { in } 1998 \text {. District Court } \\
\text { denied cross-motions for } \\
\text { summary judgment. Case } \\
\text { settled on eve of trial. }\end{array}$ \\
\hline 5 & $\begin{array}{l}\text { In re Irene } \\
\text { Korhumel }\end{array}$ & No. 11-cv-5557 & $\begin{array}{l}\text { (N.D. Ill. Aug. 15, } \\
\text { 2011). }\end{array}$ & $\begin{array}{l}\text { The Estate of Irenen } \\
\text { Korhumel sued for the } \\
\text { official rights of the Renoir } \\
\text { painting, Paysage Pres de } \\
\text { Cagnes. Richard Semmel, } \\
\text { the original owner, was } \\
\text { forced to sell his art } \\
\text { collection after he was cut } \\
\text { off from his business and } \\
\text { therefore his income. } \\
\text { Therefore, it was a } \\
\text { question of whether the } \\
\text { Korhumels or the heirs of } \\
\text { Semmel owned the } \\
\text { painting. After the } \\
\text { complaint was filed, the } \\
\text { case was settled for an } \\
\text { undisclosed amount. }\end{array}$ \\
\hline
\end{tabular}

Cases Still Pending in District Court

\begin{tabular}{|c|l|l|l|l|}
\hline & Case Name & Case Number & $\begin{array}{l}\text { Citation or Court in } \\
\text { Which Pending }\end{array}$ & Disposition \\
\hline 1 & $\begin{array}{l}\text { Cassirer v. } \\
\text { Kingdom of } \\
\text { Spain }\end{array}$ & $\begin{array}{l}\text { Nos. 06-56325, } \\
06-56406\end{array}$ & $\begin{array}{l}\text { 616 F.3d 1019 (9th } \\
\text { Cir. 2010), cert. } \\
\text { denied, 131 S. Ct. } \\
3057 \text { (2011). }\end{array}$ & $\begin{array}{l}\text { Court denied Spain's } \\
\text { motion to dismiss on FSIA } \\
\text { ground under the } \\
\text { expropriation exception. } \\
\text { Solicitor General } \\
\text { recommended SCOTUS } \\
\text { deny certiorari, which } \\
\text { SCOTUS did. }\end{array}$ \\
\hline 2 & $\begin{array}{l}\text { de Csepel v. } \\
\text { Republic of } \\
\text { Hungary }\end{array}$ & $10-1261$ (ESH) & $\begin{array}{l}808 \text { F. Supp.2d 113 } \\
\text { (D.D.C. 2011). }\end{array}$ & $\begin{array}{l}\text { Court denied motion to } \\
\text { dismiss except as to a } \\
\text { small number of paintings } \\
\text { that were the subject of } \\
\text { prior proceedings in } \\
\text { Hungary. }\end{array}$ \\
\hline
\end{tabular}


2012] FIGHTING CORRUPTION OF THE HISTORICAL RECORD

\begin{tabular}{|c|c|c|c|c|}
\hline 3 & $\begin{array}{l}\text { Maestracci v. } \\
\text { "Seated Man } \\
\text { With a Cane" }\end{array}$ & 11 CIV 7710 & $\begin{array}{l}2011 \text { WL } 5142960 \\
\text { (S.D.N.Y. Oct. 28, } \\
\text { 2011). }\end{array}$ & $\begin{array}{l}\text { Action for declaratory } \\
\text { judgment and replevin of } \\
\text { Modigliani painting } \\
\text { located at the Helly } \\
\text { Nahmad Gallery in New } \\
\text { York City. }\end{array}$ \\
\hline 4 & $\begin{array}{l}\text { Victims of } \\
\text { Holocaust Art } \\
\text { Theft v. Czech } \\
\text { Republic } \\
\end{array}$ & $\begin{array}{l}\text { 12-80420-CIV- } \\
\text { COHN }\end{array}$ & $\begin{array}{l}\text { (S.D. Fla. April 19, } \\
\text { 2012). }\end{array}$ & $\begin{array}{l}\text { Action for declaratory } \\
\text { judgment and restitution or } \\
\text { replevin, or both, of "The } \\
\text { Popper Collection." }\end{array}$ \\
\hline 5 & $\begin{array}{l}\text { Fischer v. } \\
\text { Erste Grp. } \\
\text { Bank }\end{array}$ & CV 12-3328 & $\begin{array}{l}\text { (E.D.N.Y. July 5, } \\
\text { 2012). }\end{array}$ & $\begin{array}{l}\text { Action for declaratory } \\
\text { judgment and restitution or } \\
\text { replevin, or both, of the } \\
\text { contents of a safety deposit } \\
\text { box. Action for restitution } \\
\text { for value of the bank } \\
\text { accounts, loss of a } \\
\text { mortgaged building, lost } \\
\text { salary, pension and other } \\
\text { employment benefits. }\end{array}$ \\
\hline
\end{tabular}

